\title{
„Temerin - az én hazám": változó interetnikus viszonyok magyar szemszögből és rajzban elmesélve
}

\section{"Temerin - my homeland": changing interethnic relations from Hungarian point of view and depicted in drawings}

\author{
ERŐSS ÁGNES, VÁRADI MONIKA MÁRIA
}

\section{Érkezés és első benyomások}

Magyarországi és vajdasági kutatókból álló csoportunk 2010 májusában járt először együtt Temerinben. Újvidék felől érkezve hajtottunk végig Temerin főutcáján a központban található községháza felé. A családi házas utcaképet csak helyenként tarkította a szocialista időkben épült, többemeletes kockaház. A forgalmas főutcán porfelhőt kavaró kamionok haladását a földekre tartó traktorok és legkülönfélébb munkagépek lassabb menete tartóztatta fel. A lüktető nagyváros, Újvidék sokemeletes épületei, a díszburkolatos sétálóutcákon korzózó emberáradat után Temerin egy szorgos hétköznapi életébe merülő nagy falu benyomását keltette. A községházán tett bemutatkozó látogatást követően helyi kísérőinkkel indultunk megnézni Temerint; különösen a háborús menekültek lakóhelyeire voltunk kíváncsiak. Autóink észak felé már jócskán a település végénél jártak, amikor az utolsó házat elhagyva, a sarjadó vetéstől zöldellő parcellák mögött feltünt egy pár utcából álló házcsoport. A foútról behajtva Temerin többi részétől eltérő utcakép fogadott: szorosan egymás mellé épített, kerítés nélküli, kicsi hátsó kertekkel rendelkező és jórészt vakolatlan házak sorakoztak (3. melléklet). Az összesen öt utcából álló, szabályos négyzet alaprajzú területen a délszláv háborúk után idemenekült és Temerinben letelepedő, főként horvátországi és boszniai szerb migránsok építették fel házaikat. A település többi részétől fizikailag elkülönülő (Temerinnel akkor utca nem kötötte össze közvetlenül, csupán a fóutról volt megközelíthető) és építészeti megjelenésében is elütő negyedet a befejezetlenség és ideiglenesség hangulata lengte körül (4. melléklet). A gyors körbeautózás után visszatértünk Temerin utolsó utcájába, ahol egy svájci alap támogatásával ugyancsak a szlavóniai menekülteknek felépített mintalakótelepet mutattak meg vendéglátóink (5. melléklet). Ez utóbbi is idegen testként ékelö-

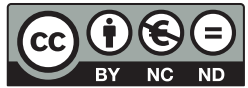


dött a családi házas környezetbe, a muskátlisládára méretezett parányi franciaerkélyek rácsai közül kitüremkedő, dióval teli vagy hagymás zsákok pedig arról tanúskodtak, hogy a lakók számára sem zökkenőmentes az új környezethez való alkalmazkodás.

Az első látogatás során eldöntöttük, hogy vajdasági kutatótársaink mellett mi is szeretnénk pontosabb képet kapni arról, hogy miként élnek együtt/egymás mellett „őslakosok” és „betelepülők”/„menekültek”. A látványos lakóhelyi elkülönülés vajon megjelenik-e Temerinről alkotott képükben? 2011-ben kétszer is jártunk Temerinben, először magyar lakosokkal készítettünk félig strukturált interjúkat. ${ }^{1}$ Az interjúk során a megkérdezettektől azt kértük, hogy meséljék el életük történetét, s rákérdeztünk a szerbekkel való együttélés tapasztalataira, ahogy azt a kérdést is feltettük, ők miért maradtak Temerinben, másokhoz hasonlóan miért nem távoztak a háborús években. Később a helyi iskolákban, szerb és magyar tanulók körében mentális térkép rajzoltatásával próbáltunk képet kapni a helyi fiatalok fejében élő Temerinről. A mentális térkép alkalmazása mellett szólt, hogy viszonylag könnyen szerezhető vele nagyobb számú válasz, illetve a módszer az esetünkben felmerülő nyelvi nehézségeket is oldja valamelyest. ${ }^{2}$ Természetesen a diákok Temerin-képére azért is kíváncsiak voltunk, mert a magyar nyelvű sajtóban hosszú évek óta úgy szerepel a község, mint a magyar és szerb fiatalok közti atrocitások, verekedések, etnikai feszültségek terepe. Jelen írásunkban a nemzetiségi együttélés, a szerbekről mint a „másikról” alkotott képek témakörét igyekszünk körbejárni, elsőként az interjús tapasztalatok összegzésével, amelyet a mentális térképek elemzése követ.

\section{Temerini párhuzamos világok: „menekültek” és „őslakosok”}

Temerin több nagy telepítési hullám során formálódott - lásd bővebben Nagy és Tátrai (2013) tanulmányát. Ezek közül a legutóbbi és máig tartó népességbeáramlást a délszláv háborúk nyomán, fóleg Szlavóniából és Boszniából menekülő szerbek megtelepedése jelenti. ${ }^{3}$ A többezres menekülthullám levonulását követően hatezren maradtak tartósan az Újvidékhez közel fekvő községben. A menekültek jó része korábban idetelepedett családtagok hívására, tanácsára érkezett, e kapcsolati háló sokat segített a migrációs döntés meghozatalában és az élet újraindításában is (lásd bővebben Ristić, Nagy, Kicošev 2013a). A menekültek lakásgondjainak megoldására a község külső részén, a piaci áraknál olcsóbban építési telkeket biztosítottak, ${ }^{4}$, ,...ez Šešeljtelep, Šešeljgrad. A magyarok nevezték el, némi iróniával, de azóta már a szerbek is így hívják" - fogalmazott egy interjúalanyunk. Az elnevezés arra utal, hogy sokak vélekedése szerint a szerb nacionalista politika szándékosan irányított ide szerb menekülteket, hogy ezzel növeljék a szerb jelenlétet, a szerb népesség számát és arányát a vegyes etnikumú Vajdaságban. E politika egyik emblematikus figurája volt - a napjainkban 
Hágában fogva tartott és háborús bűnökkel vádolt - Šešelj vajda. Az „irányított migráció" narratívája nagyon erősen jelen van mind a Temerinben élő, mind a Vajdaságból elvándorolt interjúalanyaink történeteiben. Egy helytörténeti kérdésekkel is foglalkozó író beszélgetőpartnerünk a következőképpen írta le a helyi változásokat:

„A Šešelitelepet abból a tízezer menekült egy részéból hozták létre, akik 1995ben a horvátországi, az ún. Vihar hadmüvelet (...) során a Vajdaságba menekültek. Erröl különféle adatok forognak közkézen, a 140 000-tól a 300 000-ig, hogy hány embert telepitettek be a '95-ös menekülthullám során. A lényeg, hogy ók ilyen tekintetben spontán módon jöttek ide, de az irányított volt, mert tudatosan irányitották a Vajdaság felé óket. Akikkel öszintébben lehet beszélni, nem is titkolják, hogy nekik azt mondták, hogy a Vajdaságba kell menni, mert ott üresek a házak, mert a magyarok vagy már elmentek, vagy el fognak menni."

A lezajlott változások nagyságrendjét és jelentőségét a gyermekkori emlékeket és a jelent összehasonlítva egy idősebb, 1931-ben született beszélgetőpartnerünk szavai érzékeltetik:

„(...) apánk tiltotta, hogy kiszökjünk az utcára, ő ezt így mondta, tehát nem volt szabad kimenni az utcára játszani, csak az ő engedélyével. És mi két dolog miatt mentünk ki az utcára, szöktünk ki: az egyik, amikor autó vagy traktor haladt el az utcán, a másik meg, ha nem magyarul beszélt valaki. Akkor kimentünk és megnéztük, hogy ez most micsoda. Hát, ma már akkor megyek ki, amikor magyarul beszélnek." (K., újságíró, Temerin)

A magyarok népességfogyása, arányának csökkenése, ${ }^{5}$ valamint a szerbek létszámának növekedése és térnyerése a vajdasági - $\mathrm{s}$ nem egy esetben a Magyarországon élő migráns - magyarokkal készített interjúk egyik visszatérő narratívája. A visszafordíthatatlannak ítélt folyamatot interjúpartnereink a boszniai, horvát, koszovói háborús menekült szerbek részben spontán, részben irányított betelepedéséhez kötik, amely radikálisan átalakította a lokális (és tartományi szintü) etnikai viszonyokat, s amely az együttélés, a szomszédsági kapcsolatok új gyakorlatait és diskurzusait hozta létre.

„Az igazság az, hogy elöször, mikor az első honfoglalás volt szerb részról, akkor száz családot idetelepitettek, van egy település, úgy hívják, hogy Kolónia. Azok bizony óvakodva éltek, igyekeztek simulni, hogy mondjam, hozzászokni az itteni élethez. Aztán késóbb, a második világháború után, mikor jöttek szerbek, azok szintén, volt egy egész német utca itten, és azt betelepítették bosnyákokkal. Azok is átvették a magyar szokásokat jóformán. Dolgozik a temerini, munkás nép és szorgalmas, és ők is átvették ezeket a munkaszokásokat, amit a temerini magyarok csinálnak. Csak éppen ez az utolsó, a mostani horvát, szerb viaskodásban, ezek, akik most idetelepültek, újak, ezek valahogy nem akarják tudomásul venni azt, hogy ớk az idegenek, és mi őshonosak vagyunk. Méghozzá szerintem azért, mert nekik meg lett magyarázva annak idején, mikor idetelepültek, mikor onnan elzavarták, de volt olyan is, hogy 
önkéntesen eljöttek, meg maguk is okai voltak, és persze nem mernek visszamenni oda, és azt akarom mondani, hogy, hogy mondjam? ök nem keresik a mi barátságunkat, vagy mit tudom én. Vannak ilyen falfirkák, ami arra enged utalni, hogy itt valaki vezet valami forgatókönyvet, hogy ez így menjen, hogy riasszák a magyarokat. Mert, ezt akartam mondani, mikor idejöttek, az lett nekik mondva, hogy minket innen szépen kihajtanak, kizavarnak, Magyarországra, az a Šešelj mester, aki most ott van Hágában, azt mondta, hogy kapunk egy szendvicset, hogy meg ne haljunk a határig, és akkor mehetünk. Söt, azt is mondta, hogy a tótok, a szlovákok, azok kapnak kettőt, mert ók tovább mennek. (nevetve)" (M., 70 éves nyugdíjas)

Temerinben magyar nézőpontból különbséget tesznek a különböző történelmi időszakokban (Trianont és a 2. világháborút követően) betelepedett - M. szavaival „honfoglaló” - szerbek csoportjai között. Míg a korábban érkezetteket az akkor többséget alkotó és az együttélés szabályait meghatározó magyarok szokásaihoz, munkakultúrájához idomuló, alkalmazkodó, magukat meghúzó, „integrálódott" s lényegében őshonossá vált csoportként mutatják be, addig a kilencvenes években érkezett, menekültnek vagy telepesnek nevezett emberek „idegenekként” jelennek meg az elbeszélésekben, akik nem akarnak alkalmazkodni az őshonos lakosság szokásrendjéhez, nem képesek és nem is hajlandóak az integrálódásra. Mi több, nem is keresik a közeledést, a kapcsolatot az őshonos lakossággal, legalábbis az idézett interjúalany szerint, aki azt is tudni véli, hogy az újonnan érkezettek között nem mindenki ártatlan menekült.

Az új „telepesek” viselkedésének forrását magyar beszélgetőtársaink részben a háborús idők erőszakos, máig ható szerb nacionalizmusára és a Vajdaságot is érintő etnikai homogenizációs törekvésekre vezetik vissza - erre utal a Vojislav Šešeljre való hivatkozás az interjúrészletben -, vagy döntően az „őshonos” és új telepes lakosság közötti kulturális, civilizációs, mentalitás- és magatartásbeli különbségek mentén értelmezik. Az új migránsok jellemzésére gyakran használt „hegyi” metafora, a sík Vajdaság és a boszniai hegyvidék implicit szembeállítása révén földrajzi jelentéssel is bír, ám a „hegyiek” megjelenésük, viselkedésük révén is azonosíthatók. „A hegyi ember egész másképp lépked, mint az, aki az alföldön él”; nem a járdán, hanem az utca közepén közlekednek, mert lakóhelyükön nem volt járda; egyfelől lusták, másfelől nyersek, mozgékonyak, erősebbek, mint az itt élők. Ahogy egyik beszélgetőpartnerünk összefoglalóan fogalmazott, „azok nem középeurópai, azok balkáni emberek”.

A „szerbekről” mint a „másikról” szóló narratívák akaratlanul is az orientalista diskurzus hagyományaihoz illeszkednek (Bakić-Hayden 1995, lásd még Váradi 2013 tanulmányát e számban), jellemzően homogenizálnak (az őshonosnak tekintett és az új telepes lakosok egységes, differenciálatlan csoportként jelennek meg), és nem feltétlenül kapcsolódnak az együttélés során szerzett személyes tapasztalatokról szóló narratívákhoz. Temerini magyarokkal készített interjúink során nem hallottunk menekültekkel ápolt személyes, baráti kapcsolatokról. 
Egyik interjúpartnerünk arról mesélt, hogy munkába menet a buszról nap mint nap látja az új telepet, ahol a menekültek élnek, de soha nem járt ott, nem is ismer onnan senkit. A telepnek ugyan nincs rossz híre, állítja, de „azt a részt annyira nem kedveljük", s a „hegyiekről” alkotott véleményét a buszmegállóban beszélgeto „most már bennszülött, beilleszkedett régebbi telepes” szerbekre hivatkozva támasztja alá.

„Az nekem nagyon érdekes volt, mikor ketten beszélgettek egy harmadikról, és a harmadikról leritt, hogy az valahogy most jött ide. És akkor úgy véleményezték, hogy ez is itt, hogy gondolja, egy kecskével itt majd megél. Meg ilyen hasonlók. Nem akar dolgozni, meg ilyen. Nagyon nem kedvelik öket, és azt, hogy nem kedvelik öket, azt úgy ki is nyilvánítják." (Z., 44 éves pedagógus) A szerbek közötti különbségekre való utalás - a régebben itt lakók maguk is lenézik a civilizálatlan, dologtalan újonnan érkezetteket - egyrészt megerősíti a magyar és szerb „őslakosok”, valamint a szerb „idegenek” közötti szimbolikus határokat, másrészt igazolja, legitimálja a magyarok új telepesekről alkotott képét. ${ }^{6}$

A „másikról” alkotott sztereotip kép, az elhatárolódások és határmegvonások finom rendszerét illetően érdekes párhuzamra hívja fel a figyelmet a vajdasági Lovćenacon (Szeghegy) 2009-ben végzett kutatás, amely a második világháború után a németek helyére érkező montenegrói telepesek (jórészt partizánok) identitását, szomszédsági viszonyait vizsgálta. A kutatás többek között rámutatott arra, hogy a lovćenaci telepesek mind a falu magyar lakosságától, mind a közeli településeken (Fetekić/Feketics, Mali Iđoš/Kishegyes) élő, Montenegró más vidékeiről származó crnagorácoktól és boszniai szerbektől elhatárolják magukat. A magyarok szemében a lovćenaci montenegróiak lusták, nem értenek a földműveléshez és agresszívek, szöges ellentétben a korábban ott lakó, szorgos és kitűnően gazdálkodó németekkel. A Lovćenacban új otthonra talált montenegróiak pedig - bár nem bíznak a magyarokban - a feketicsi és kishegyesi montenegróiaktól is elhatárolódnak, kevésbé férfiasnak, illetve kulturálatlan, hegyek között felnőtt, durva embereknek tartják őket (lásd a „hegyiek" metaforáját). A közeli Verbászon (Vrbas) letelepedett boszniai szerbeket pedig gyakran „bosnyákok”-ként emlegetik, akik - megítélésük szerint - térben is elkülönülten élnek, és mindig valamilyen újabb ügyeskedésen, üzleten törik a fejüket (Nedeljković 2011, é.n.).

Ami Temerint illeti, óvatosan kell fogalmaznunk, hiszen kutatócsoportunk sem a magyar, sem a szerb temerini lakosokkal nem készített sok interjút, mégis úgy gondoljuk, hogy jelzésértékű a narratívák szembetűnő különbsége. Míg a szerb menekültek arról beszéltek, hogy úgy érzik, az „öslakosok” elfogadták őket és integrálódtak a helyi társadalomba, valamint szerbekhez és magyarokhoz kötődő jó kapcsolataikról számoltak be (Ristić, Nagy, Kicošev 2013a), addig a magyarok elbeszélései erős, jószerivel áthághatatlan szimbolikus határokra utalnak, s az új „telepeseket” lényegében beilleszkedésre alkalmatlan és arra nem is hajlandó homogén csoportként mutatják be. A kétféle narratíva elbeszél egymás mellett, radikálisan eltérő tapasztalatokra utal és egymástól gyökeresen 
különböző Temerin-képet hoz létre. Úgy is fogalmazhatnánk, hogy a narratívák maguk is hozzájárulnak a határok masszív fennmaradásához, ugyanakkor kifejezik és meg is erősítik a helyi társadalmon belüli mély hasadást. A felszínen, a nyilvánosság előtt a fiatalok közötti konfliktusok utalnak e mélyebb, rejtettebb törésre és feszültségre.

\section{„A vajdasági lakmuszpapír"}

A sajtóban megszólalók gyakran használják az idézett metaforát Temerinre, amely azt hivatott kifejezni, hogy a soknemzetiségü Vajdaságot feszítő konfliktusok aktuális hőfokát és állapotát pontosan le lehet mérni a településen zajló eseményeken. Temerinben a nagyszámú háborús migráns érkezésével új terek - elsősorban a menekültek által lakott, etnikailag homogén telep ${ }^{7}$ - jöttek létre, új térhasználati gyakorlatok alakultak ki, amelyek folyamatosan fenntartják, újratermelik az etnikai, kulturális, szimbolikus határokat, és mint ilyenek, konfliktusokkal terhesek. Temerin a szerb és magyar fiatalok közötti erőszakos összetűzéseknek köszönhetően gyakran szerepel a médiumokban. Jelen írásnak nem lehet és nem is célja a rendkívül komplex és mindeddig feltáratlan temerini konfliktusok bemutatása, kiváltképp elemzése. A megértés érdekében viszont szükségesnek tartjuk néhány alapmotívum felvázolását, hiszen - ahogy látni fogjuk - a konfliktusok nyomán fellépő erőszak tagadhatatlanul bekerült a 13-18 éves korosztály Temerin-képébe.

Az interneten elérhető vajdasági magyar nyelvű sajtóanyagok közül a Magyar Szó, a Temerini Újság és a Vajdaság Ma internetes portáljain kerestünk rá a Temerin szóra; a 2010 és 2013 közötti időszakban megjelent cikkeket néztük át. A több száz Temerinnel foglalkozó írás közel kétharmada a Temerinben történt atrocitásokkal és az arra adott politikai, közéleti reakciókkal foglalkozik. E sajtóanyag átfésülése után is kirajzolódik egyfajta ismétlődő konfliktus-forgatókönyv. Az aktuális események kirobbanásának oka vagy egy verekedés, ${ }^{8}$ vagy gyülöletkeltő falfirkák ${ }^{9}$ megjelenése, esetleg rágalmazás. ${ }^{10}$ Az utóbbi két esetben egyértelműen azonosítható az etnikai indíttatás, amelyet követően, ha az érintett feljelentést tesz, rendőrségi nyomozás indul. A könnyü vagy sajnos gyakran súlyos sérüléssel járó verekedéseket túlnyomórészt magyar és szerb fiatalok követik el, általában csoportosan, belvárosi szórakozóhelyek környékén, hétvégenként. Az ügy innen a rendőrség, majd a nyomozás lezárulta után az ügyészség, végül a bíróság elé kerül. Az eseményeket a kezdetektől élénk média- és politikai figyelem övezi határokon kívül és belül, ezáltal a lokális konfliktus országos, sőt mind a magyar, mind a szerb oldal számára nemzetpolitikai jelentőségűvé válik. Míg a szerbiai sajtóban Koszovóval állítják párhuzamba a Vajdaságot, ahol a szerb érdekek és lakosság, végső soron az állam egysége egyaránt védelemre szorul, addig a magyar nyelvü médiában a magyar kisebbség 
megfélemlítéséről, a nemzetiségi jogok sérelméről beszélnek. A sajtóban hamar, jellemzően még a nyomozás lezárása előtt etnikai alapú incidensként tárgyalják az eseteket, sürgetve a minél magasabb szintű politikai válaszlépéseket és a rendfenntartói beavatkozást. A temerini fiúk ügye ${ }^{11}$ a legmagasabb állami szintű (miniszterelnöki és elnöki) találkozók témájává vált. A magyar nyelvű sajtóban és interjúkban a következő értelmezési modelleket azonosítottuk:

- E modell szerint a konfliktust külső érdekek, szélsőségesek gerjesztik, amit a médiumok túldimenzionálnak: ezen értelmezés szerint a helyi lakosok békés együttélését külső, szélsőséges politikai erők igyekeznek megbontani. Néhány felvonulást szervező magyar fiatalról kiderült, hogy a Hatvannégy Vármegye Ifjúsági Mozgalomhoz kapcsolhatók, míg falfirkákat festő szerb fiataloknál az Obraz ${ }^{12}$ nevü szerb szélsőjobboldali mozgalom plakátjait találták meg. Azok, akik a konfliktusokat így értelmezik, érveikben a Vajdaság hagyományos multietnikus múltjára, illetve személyes soknemzetiségü kapcsolataikra hivatkoznak.

- A „kettős mérce” értelmezési modellje szerint a nyomozás, de főként az ítélkezés során az eljáró szervek etnikai alapon aránytalanul súlyosabb büntetést rónak ki a magyar nemzetiségü elkövetőkre, mint a szerbekre.

- A konfliktus a beilleszkedni nem akaró/tudó menekültekhez köthető, illetve a betelepítésük mögött meghúzódó, etnikai homogenizációra törekvő szerb politika egyik következménye. Ezen erők végső célja a magyarok megfélemlítése és távozásuk kikényszerítése.

- „A kilencvenes évek hordaléka” értelmezés szerint a temerini konfliktusok a délszláv háború rémét idézik fel, akik így érvelnek, azok a Jugoszlávia felbomlásához vezető idők eseményeihez hasonlítják az atrocitásokat és kezelésüket.

Az erőszak forrásvidékének feltárása összetett feladat, amelyre nem vállalkozhatunk. Annyi azonban bizonyosnak látszik, hogy az elmúlt húsz évben a temerini fiatalok egymással alig érintkező etnikus világokban nőnek fel. A településen a jugoszláv időkben egy magyar és egy vegyes összetételű általános iskola működött. A kilencvenes években a menekültek érkezésével megnövekedett a szerb anyanyelvü gyerekek száma, s ők a vegyes iskolába kerültek, ahonnan helyhiány miatt a magyar osztályokat átköltöztették a magyar iskolába. Noha az eredetileg vegyes - mára homogén szerb - iskola a menekültek lakta telepen már egy új épülettel is rendelkezik, úgy tűnik, senki nem kezdeményezi, hogy újra működjön a városban vegyes etnikai összetételü általános iskola. ${ }^{13}$ Amikor 2011 őszén a tartományi ombudsman utalt arra, hogy „a nemzetiségek közötti békés együttélés szempontjából sokkal kedvezőbb lenne, ha ismét vegyes tannyelvü általános iskolák működnének Temerinben", a helyi Vajdasági Magyar Demokrata Párt elutasította az álláspontot, mondván, az incidenseknek „semmi köze sincsen ahhoz, hogy a településen két különálló iskolában tanulnak magyar és szerb diákok". A helyi politikai vezetők pedig a magyar közösség meggyengítésének kísérleteként értelmezték az ombudsman szavait. ${ }^{14}$ 
Annak ellenére így van ez, hogy elsősorban (de nem csak) pedagógus beszélgetőtársaink is hangsúlyozták, hogy a gettósítás és öngettósítás nehezíti a gyerekek közötti interetnikus kapcsolatok kialakulását, és ez nemcsak az oktatási intézményrendszeren belül, de az iskolán kívüli világban is etnikailag szegmentált térhasználati, közösségi gyakorlatokat alakít ki. Mintha a sport lenne az egyetlen terület, ahol a magyar és szerb fiatalok megismerhetik egymást, ahol barátságok is kialakulhatnak. ${ }^{15}$

„(...) itt azért gettósítva vagyunk. Itt az iskolában csak magyarok, ott csak szerbek. Én nem tartom jónak. Mert a gyerekek teljesen külön vannak, és nem barátkoznak. Kivételt képeznek azok, akik esetleg edzésekre járnak, és ott találkoznak szerb gyerekkel. Az én kisfiam is jár futballra, és ott rengeteg szerb barátja van. És bizony elvan velük, és beszélgetnek. Szerintem ez a normális, ez a jó. Nem jó dolog az, hogy a magyar gyerekek magyar szórakozóhelyekre járnak, ahol tudják, hogy oda csak magyar megy. Vagy olyan étterembe, ahova csak magyarok járnak, vagy iskolába. Én nem tartom személy szerint jónak ezt. Ez nem azt jelenti, hogy most jó lenne összekeverni, tehát hogy most csináljunk egy nagy bummot, hozzunk ide két szerb osztályt, meg oda vigyünk két magyart. Nem ezt akarom mondani." (Sz., magyar pedagógus) Úgy tünik, hogy az etnikus együttélés mintázatait erőteljes generációs törésvonalak alakítják. Annak ellenére, hogy az idősebb generációhoz tartozó temerini magyar interjúalanyaink kérdezés nélkül is beszéltek a második világháború végén a községben kb. 300 magyar áldozatot követelő partizánmegtorlásokról, a családi és közösségi veszteségekből fakadó, jellemzően tabusított trauma - interjús tapasztalataink szerint - nem feltétlenül vetül rá a jugoszláv idők emlékezetére. Beszélgetőpartnereink ugyanis e korszakot felidézve a viszonylagos jólét mellett a lehetséges békés etnikus együttélés tapasztalatáról is beszámoltak - lokális, tartományi és országos szinten egyaránt (szerb barátok, kollégák, egyetemi társak, katonaság, sport stb.).

A középgenerációhoz tartozó, 1969-ben született pedagógusnő a temerini vegyes összetételű általános iskolába járt. Éveken át kosárlabdázott, társai többsége (Boszniából érkezett) szerb volt; többekkel máig tartó barátságot kötött, iskolásként a leckeírásban és a nyelvtanulásban is segítették. Emlékezete szerint sem az iskolában, sem a sportban „nem számított a magyar származás”, abból soha semmilyen hátránya nem származott. A középiskolában pedig szerbtudása miatt könnyebben boldogult, mint azok, akik magyar környezetből és iskolából érkeztek. A vegyes környezet, állítja, nyitottá tette őt, s ez a nyitottság mintha hiányozna a fiatalabb generációkból. A kisebbségben élő fiatalok elszigetelik magukat, ha nem tudatosul bennük, hogy magyarként ugyan, de Szerbiában élnek, s ha csak a maguk közegében mozognak, az államnyelvet sem sajátítják el megfelelően - hangsúlyozza. A viszonyok aszimmetrikussá válására utalva azonban megjegyzi, jó lenne, ha a szerbek is nyitottak lennének a magyarok, a magyar nyelv felé.

Ez a nyitottság a titói időkben (ha kényszerből is) hétköznapi szinten például megnyilvánult a környezeti nyelv kötelező tanításában, mely a mai Szerbi- 
ában teljesen hiányzik. Egyesek a szerb nemzetállam homogenizáló politikájának újabb eszközét látják ebben, mások viszont arra figyelmeztetnek, hogy az egymás nyelvét nem beszélő felnövő generációk között nem is tud olyan jószomszédi viszony kialakulni, amely a multietnikus Vajdaság sajátja és egyedi arculatának meghatározó eleme.

\section{A mentális térképek felvételezésének körülményei - az „aktualitásfaktor" a terepmunkán}

A mentális térképek rajzoltatásáról 2011 tavaszán személyesen egyeztettünk a temerini Kókai Imre Általános Iskola igazgatójával, aki támogatásáról biztosított, egyúttal segítséget ajánlott a szerb iskolába való eljutáshoz.

2011. október 5-én, az előzetesen egyeztetett reggeli időpontban megérkeztünk ${ }^{16}$ a magyar iskolába. A szeptemberi tanévkezdést követő hetekben három, magyar és szerb fiatalok közti verekedés is történt (szeptember 11-én, 25-én és 26 -án), majd a város legnagyobb magyar tulajdonú pékségét azzal vádolták meg, hogy nem ad el kenyeret szerbeknek. A szerbek érdekeit védendő az Obraz szélsőjobboldali szerb szervezet tüntetést hirdetett szeptember 25-re a város központjába, melytől engedély hiányában visszalépett. Szeptember 30-án a rendőrség nyolc, egy kivétellel fiatalkorú személyt közrend megzavarása miatt vett őrizetbe. Többüknél fahusángot, láncokat, szerb nemzeti és Obraz-zászlókat foglaltak le. A rendőrség az atrocitások esélyét csökkentő intézkedésként megerősített járőrszolgálatot vezényelt Temerin központi részeire. ${ }^{17}$

$\mathrm{Az}$ adott helyzetre való tekintettel többen is figyelmeztettek bennünket arra, hogy nem a legszerencsésebb időpontban érkeztünk terepmunkát végezni, hiszen az egész város olyan, mint a felbolydult méhkas. Hallhattunk olyan véleményt is, hogy a szerbek biztosan rengeteg akadályt fognak gördíteni a munka elé, hiszen magyarországi magyarok vagyunk, és olyan felmérést akarunk készíteni, amelybe magyar és szerb fiatalokat kívánunk bevonni, mintegy provokálva őket. Miután a magyar általános iskolában gyorsan végeztünk a rajzok összegyűjtésével, próba szerencse alapon, a nálunk lévő angol nyelvű intézeti támogató levél birtokában átsétáltunk a Lukijan Mušicki Középiskolához. ${ }^{18}$ Itt az ügyeletes diáklány kedvesen elmagyarázta, hol találjuk az igazgatói irodát és a tanárit. Néhány perc várakozás után fogadott az igazgató, akinek angolul röviden elmondtuk, honnan jöttünk és mi járatban vagyunk. Mutattuk volna a pecsétes papírt, de hamar kiderült, hogy nyitott kapukat döngetünk; nagyon szívesen felajánlotta a diákok nevében is a segítséget, csak annyi türelmet kért, amíg kicsöngetnek az óráról, és a megfelelő osztályok (11.-es magyar tagozatos és szerb tagozatos osztályokba szerettünk volna eljutni) tanárnőinek be tud mutatni. A beharangozott nehézségek egyikét sem tapasztaltuk, sőt gördülékenyen és gyorsan ment a felvételezés a középiskolában is. 
A két iskolában összesen 97 mentális térkép készült, ebből 45 a Kókai Imre Általános Iskolában (a 3. és 4. osztályban 23, egy 7. osztályban 22). A Lukijan Mušicki Középiskolában összesen 52 (11.-es osztályok), ebből egy magyar tanítási nyelvü osztályban 24, egy szerb tanítási nyelvüben 28. A tanárok kíséretében és engedélyével az óra elején összesen tíz-tíz percet vett igénybe a felvétel. Az osztályoknak röviden bemutatkoztunk, elmondtuk, hogy Budapestről érkeztünk, a Magyar Tudományos Akadémia egyik kutatóintézetéből és egy svájci támogatású projekt keretében végzünk kutatást Temerinben. Igyekeztünk hangsúlyozni, hogy a kutatás nemzetközi, szerbiai és magyarországi kutatók is részt vesznek benne. Az üres A4-es lapok kiosztása előtt és azt követően is elismételtük a kérést: Rajzold le Temerint, ahogy te látod! Azért döntöttünk a kötetlen felidézésen alapuló térképrajzoltatás (Letenyei 2005, 167.) mellett, hogy minél kevésbé befolyásoljuk a diákok mentális térképének felidézését. A kérés megfogalmazásakor szándékosan hagytuk ki a térkép szót, mivel az korábbi tapasztalataink szerint rendszerint zavarba hozza és elbizonytalanítja a válaszadókat, valamint nem szerettük volna csupán térképekre korlátozni a gondolkodást. A kutatástól azt reméltük, hogy képet alkothatunk arról, hogy a diákok Temerin mely részeit használják, mit tekintenek központnak, és kíváncsiak voltunk arra is, vajon a várostól elkülönülő, periferikus fekvésű telep szerepel-e a diákok kognitív térképein. Azt gondoltuk, hogy a városi térhasználatot, illetve a térről alkotott ismereteket az életkor, a nem, az iskola és a lakóhely elhelyezkedése alapvetően befolyásolja, ezért a diákoktól azt kértük, tüntessék fel nemüket, valamint azt, hogy melyik utcában laknak és hány évesek. ${ }^{19}$

A térképeket még Temerinben, a felvételezés után átfutottuk, és némi csalódással állapítottuk meg, hogy az eredeti, a térhasználat esetleges etnikai különbségeire vonatkozó kérdésünkre nem kaptunk választ. Egyúttal azonban (meglepetésünkre) azt is felfedeztük, hogy a diákok egy része a rajzokon különféle interpretációkban megjelenítette a Temerinben legutóbb lezajlott erőszakos cselekményeket, verekedéseket. Úgy véljük, hogy éppen ebben rejlik e térképek, rajzok valódi érdekessége, hiszen izgalmas adalékokkal szolgálhatnak annak értelmezéséhez, hogy a leginkább érintett korosztály, a diákok szemében hogyan jelenik meg az erőszak és az etnikai konfliktus.

\section{Amiről a térképek beszélnek}

A mentális vagy kognitív térképek elemzésével a földrajz mellett több társtudomány (szociológia, antropológia, pedagógia) is behatóan foglalkozik. Jelen keretek között csak a legáltalánosabb következtetések levonására szorítkozunk.

A mentális térképek felvételezése négy csoportban zajlott. Elsőként röviden áttekintjük, hogy melyek voltak az egyes csoportok és rajzaik fö jellemzői, ezt követően részletesen csak azokat elemezzük, amelyeken az etnikus tartalom és az erőszak ábrázolása hangsúlyos elemként megjelent. 


\section{A mentális térképek általános jellemzése}

Az első csoportban a Kókai Általános Iskola kilenc-tízéves diákjai által rajzolt képek találhatók (összesen 23 darab). Ezeken a rajzokon leginkább a közvetlen környezet (családi ház, utcarészlet: 3 darab), Temerin központja, a forgalmas foút és a közlekedés/közlekedők (15 darab), természeti képek (tó, park: 5 darab) jelennek meg. A rajzok többsége nagyon színes (mindössze három fekete-fehér grafitrajz készült) és aprólékosan kidolgozott (virágok, madarak, üzletek neveit is feltüntették). A diákok jellemzően a rendelkezésre álló teljes felületet igyekeztek kitölteni, színezni. Ebből a csoportból egy rajz sem került be a részletes elemzésbe.

A második csoportot a Kókai Általános Iskola 7. osztályosai által készített képek alkotják. Az összesen 22 rajzot fele-fele arányban készítették fiúk és lányok. A kisebbekhez hasonlóan itt is találtunk két, csupán egy-egy házat ábrázoló rajzot, három további rajzon egy-egy egyszerủ térkép szerepel, útirányok megnevezésével. További négy rajzon csak az iskola skicce látható. Öt rajz örökített meg park- vagy tájrészletet, míg nyolc másikon valamilyen szimbólum vagy szimbólumok hivatottak leírni, hogyan is látja a szerző Temerint. Ebből a csoportból öt rajz kerül be a részletes elemzésbe.

A Lukijan Mušicki iskola szerb osztályában összesen 28 rajz készült, 22 lány és 3 fiú rajzait tudtuk begyüjteni, hárman nem tüntették fel a nemüket. Ezeken a képeken az iskola szomszédságában található parkot (8 darab) és a városi strandot (2 darab), valamint ezeket az iskolaépülettel együtt (5 darab) azonosították Temerinnel a legnagyobb számban. Kilenc rajzon szerepelnek többemeletes házak, a föutca egy-egy részlete, míg három rajzon szimbólumok, egy esetben pedig családi ház szerepel a térképen. Ebből a csoportból összesen kilenc rajzon jelent meg valamilyen etnikai vagy konfliktusra utaló tartalom.

A magyar osztály 24 rajzából tizenhatot lányok készítettek, a többit fiúk. Itt is volt három rajz, amelyeken csak egy-egy ház és annak közvetlen környezete szerepel, hat rajzon az iskola melletti park részletét tüntették fel. Tíz rajz térképszerüen ábrázolta Temerin központját vagy az iskola környékét, három képen cselekvéssorok, míg kettőn szimbólumok hivatottak bemutatni, hogyan látja a rajz készítője Temerint. Ebből a csoportból hat tükrözött valamilyen aktuális tartalmat, végül összesen nyolc rajzon azonosítható az elemzésünk szempontjából releváns információ.

Mindezek alapján 22 rajz került be az elemzésbe, ami az összes rajz 22\%-a, de ha figyelembe vesszük, hogy a temerini konfliktusokban érintett korosztály a tinédzserek és fiatal felnőttek közül kerül ki, akkor az alsós osztályokat elhagyva az összes rajz 29\%-ában található valamilyen etnikumra vagy konfliktusra utaló tartalom, vagyis a korosztály jelentős hányada, csaknem harmada fontosnak tartotta ezt valamilyen módon megjeleníteni. Sajnos a minta nemi szempontból erősen torzít a lányok javára (49 lány, 22 fiú, 4 fő nem tüntette fel a nemét), a részletesen elemzett 22 rajzban viszont kiegyenlítettebbek az arányok: 22-ből 8 fiú foglalkozott a konfliktussal, miközben a 49 lányból „csak” 14 érinti valami- 
lyen módon a témát. Azokat a rajzokat, amelyek etnikai vagy erőszakra utaló jelentéstartalommal bírtak, három, viszonylag egyértelműen elkülöníthető csoportba osztottuk, amelyeket a következőkben részletesebben vizsgálunk.

\section{1. csoport: Az etnikus jelentéstartalom megjelenése a rajzokon}

Az első csoport direkt módon közöl etnikai tartalmat a szerb (4 szerb lány, 1 szerb fiú) vagy a magyar zászló (1 magyar fiú) ábrázolásával. A nemzeti zászló az egyik legegyértelműbb és legszélesebb körben azonosítható nemzeti szimbólum. Vitatott etnikai terekben a nemzeti színek és zászlók alkalmazása az etnikai alapú politizálás egyik gyakran használt eszköze (Bodó, Biró 2000, 14-15.; Brubaker, Feischmidt, Fox, Grancea 2011, 147-148.; Erőss, Tátrai 2010; Kliot, Mansfield 1997). Az egyébként grafitceruzával készült képeknek a nemzeti színű zászlók az egyetlen színes, ezáltal még inkább szembetűnő elemei. A szerb zászlók esetenként a rajz előterében szerepelnek, általában épületeket díszítenek (egy esetben az iskolát): az ablakokból lógnak ki vagy tömbház tetején lengedeznek a szélben (6. melléklet).

Az egyik kép, amelyet egy Temerinben tanuló újvidéki lány készített, csupán pár tömbházat ábrázol, a kép előterében álló zászló alatt cirill betűvel szerepel Szerbia neve, mellette egy piros szív (7. melléklet). A diáklány rajza kevés személyes térkapcsolatról tanúskodik Temerin vonatkozásában, a szerb zászló és a hazaszeretetet kifejezni hivatott szív viszont egyértelműsíti, hogy Temerin szeretett Szerbiája része.

A magyar nemzeti zászló egy békés horgászjeleneten található. Az egyébként színes rajz készítője fontosnak tartotta a kerékpár, a horgász, a horgászszék és a pecabotok mellé a földbe szúrva megjeleníteni a magyar nemzeti trikolort. A már-már csendéletszerű kép így közvetlen etnikai jelentéstartalmat nyer, a földbe leszúrt zászló mintegy nyomatékosítja, hogy a föld magyar (8. melléklet). Az öt rajz a nemzeti szimbólumok megjelenítésével a terület birtoklását fejezi ki, amely az etnikai-hatalmi konfliktusra tett egyértelmű utalásként is értelmezhető.

\section{2. csoport: Az utcai erőszak ábrázolása}

A rajzok második csoportja az erőszakra, illetve a sajtóban gyakorta szereplő incidensekre utal. Az ide tartozó kilenc kép közül kettőt szerb lányok, hetet magyar diákok (4 fiú, 3 lány) rajzoltak. A csoportba tartozó képek közül öt Temerin egy részletét, általában a főtér környékét ábrázolja felülnézetben. A képek középpontjában, előterében valamilyen konfliktus zajlik: pálcikaemberek szaladnak a szirénázó rendőrautó és rohanó rendőr elől (9. melléklet), egy sétaúton a padok előterében egy ember fekszik a földön kiterülve, a fölötte álló, gonosz ábrázatú alak épp akkor ütötte le, amit a szövegfelhőben szereplö „,boom!” felirat közöl (10. melléklet). A háttérben látható a mentő- és a rendőrautó, valamint a középiskola jellegzetes épülete, igaz, a járművek nem utakon futnak, az üres térben szórta szét őket a rajzoló. A következő rajzon egy pálcikaemberkét 
három másik fog közre és (amennyire ez pálcikakezektől telik) ütlegel. Az egyik, teljességre törekvő rajz készítője igyekezett minél több, számára emblematikus helyet lerajzolni Temerinből: a horgásztavat, az uszodát, a parkot, a ház végi kiskerteket, a családi házas negyedet és a titói időkben épült tömbházakat. A rendkívül sűrün telerajzolt lapon pár figura is feltűnik: egy horgász, egy padon ülő és egy sétáló figura, majd a kép jobb alsó sarkában, egy gyárkémény háta mögött előtűnik három alak: egyikük magasra tartott baseballütőnek vagy fadarabnak látszó tárgyat emel ütésre, miközben társa feltartóztatja a menekülni akaró vékony alakot. A képet éppen ez a részlet teszi különösen nyomasztóvá, hiszen nagyon aprólékosan mutatja be Temerint, ahol elsőre ez a jelenet beleolvadni látszik a hétköznapi élet egyéb díszleteibe (házak, autók) és eseményeibe (sétálgatás) (11. melléklet). A tény, hogy ezen a rajzon is több alak bántalmaz egyet, aki ráadásul fegyvertelen, egyenlőtlen és tisztességtelen küzdelemre utal.

Érdekes, hogy a verekedést ábrázoló rajzokon soha nincs rendőrautó, csak azt látjuk, ahogy épp verekednek (csupán egy esetben, az üres térben áll egy rendőrautó). Azokon a rajzokon viszont, ahol rendőrautó és rendőr is szerepel, az agressziót nem ábrázolják közvetlenül. Az egyik magyar lány alkotásán Temerin központját látjuk (a községháza előtti kis teret, lámpás kereszteződést) az út több oldalán futó járdán kettesével járőröző rendőrökkel, ami hűen tükrözi a felvételezés idején aktuális megerősített rendőri jelenlétet (12. melléklet). A rajz lényegi eleme a rendőrök csoportos ábrázolása: összesen négy pár rendőrt látunk a négy gyalogos civil mellett, közülük egy pár alá szomorú arcocskát rajzolt a szerző, ezzel kifejezésre juttatva nemtetszését a sok rendőr láttán. További két rajz bulit ábrázol, söröző és kávézó előterében, ahonnan zeneszó szürődik ki a szabadban iszogató párocskák és baráti társaságok közé. Az egyik kép előterében két alak verekszik, az egyik már a földön van, a másik a hajánál fogva húzza őt (13. melléklet). Egy képen két alak ütésre emelt kézzel áll, miközben a fejük fölötti buborékba a "meghalsz” és „szétkaplak” agresszív fenyegetéseit írta a diák.

Fontos kiemelnünk, hogy ezeken a rajzokon egyetlen esetben sincs utalás a verekedők, támadók és áldozatok etnikai hovatartozására. Az atrocitást nyíltan ábrázoló rajzok csoportjában egy van, amelyik egyértelmű etnikai alapú incidenst örökít meg, illetve idéz fel. A 13 éves magyar fiú rajzán egy utcai jelenetet látunk (14. melléklet). A képen öt alak szerepel: egy sísapkás balkezes figura épp egy ház falára fújja fel az Obraz szót. A kép előterében egy ugyanolyan sapkába öltözött alak jobbegyenest oszt ki egy másiknak, akinek szeme fájdalmasan eltorzul. A kép jobb oldalán egy nő és kislánya szaladnak ki a ház oldalán, a nő kezében telefon, szája, ahogy a kislányé is, nyitva, mintha kiáltanának. A rajz nagyon hitelesnek, már-már fényképszerünek hat, amit csak erősít, hogy a rajzoló törekszik a hü emberábrázolásra, nem pálcikaembereket látunk. A nő és a kislány szerepeltetése azt fejezi ki, hogy Temerinben a civil, ártatlan (lásd kislány) lakosság nap mint nap szembenéz a szerb szélsőségesek agressziójával. Bár a képen nincs utalás arra, hogy az áldozat magyar lenne, az, hogy a falra az Obraz neve kerül és a két férfi mintegy egyenruhaszerűen, hasonló sapkát visel, arra enged következtetni, hogy a fiú etnikai alapú verekedést örökített meg. 


\section{3. csoport: Temerinröl a szimbólumok nyelvén}

A harmadik csoportba azokat a rajzokat válogattuk, amelyek absztrakt módon, szimbólumok segítségével adtak választ arra a kérdésre, hogy a diákok miként látják Temerint. Ebbe a csoportba hét rajz került, három a Kókai Imre Általános Iskolából, kettő-kettő pedig a Lukijan Mušicki Középiskola szerb, illetve magyar tanítási nyelvü osztályából. Ide soroltunk két olyan rajzot is, amelyiken Temerin mint a szeretett (színes szívektől és virágoktól övezett) haza (15. melléklet), illetve egyenesen a „világ közepe” szerepel. Ez a két rajz alátámasztja a Lukijan Mušicki Középiskolában végzett kérdőíves vizsgálat megállapítását, amely szerint a gyerekek, különösen a magyarok számára a szülőváros elsődleges fontosságú identitást alakító tényező (Ristić, Nagy, Kicošev 2013b). Egy szerb lány által készített rajz a családi házat és annak gazdasági udvarát ábrázolja meglehetős aprólékossággal és egy-egy szavas szöveges magyarázattal (16. melléklet). A korábbiakban láthattuk, hogy kérésünkre viszonylag sokan asszociáltak a saját házukra, ez a rajz azért került mégis ide, mert a lap alján, részben nyomtatott latin nagybetúkkel írt mondatok olvashatók: „AZ ÉN HÁZAM AZ ÉN SZABADSÁGOM! Az én utcámban, az én udvaromban harmónia van" / MOJA KUĆICA MOJA SLOBODICA! U mojo julici, u mom dvorištu vlada harmonija". Az igényes rajz ugyan nem ábrázol semmiféle erőszakot, a két mondat azonban a saját kerítésen belüli harmónia kiemelésével kimondatlanul is utal arra, hogy a házon kívül már nem feltétlenül harmonikus a világ. A közmondásként ható kiemelt mondat közvetve azonban azt is kifejezi, hogy a szerző azért tartja magát felelősnek, ami a házon belül történik, illetve hogy a saját ház védelmet is biztosít a kerítésen kívüli konfliktusok elől..$^{20}$

A csoport négy további rajza nyíltan utal az erőszakra mint a két etnikai csoport, a szerbek és magyarok konfliktusára. Két magyar fiatal által rajzolt képen (ők valószínűleg egymás mellett ültek a teremben a kép készítésekor) a két etnikumot képviselő szimbólumok szerepelnek, köztük a versus (vagy) kifejezésre utaló vs. rövidítéssel (17. melléklet). A magyarokat a kettős kereszt, míg a szerbeket a szerb kiscímer (szerb ortodox kereszt és a négy cirill „sz” betü) ${ }^{21}$ jelképezi. A szimbólumok éles szembeállítása, illetve a közöttük való választásra mintegy felszólító „versus” szó igen radikálisan, egymást kizáró közösségként láttatja a szerbeket és a magyarokat. Ha felidézzük, hogy a mentális térkép készítésére vonatkozó kérdés úgy hangzott: Rajzold le Temerint, ahogy látod!, akkor e rajzon a település a szerbség és magyarság közti küzdelem színtereként jelenik meg. A választásra, nyílt szembenállásra utaló „versus” azt is egyértelműsíti, hogy itt nem képzelhető el egymás melletti valóság, világ, itt mindenkinek választania és valakinek győznie kell.

Érdemes a két etnikai csoporthoz kapcsolt szimbólumokról pár szót ejteni. A diákok a magyarok és a szerbek esetében is a kereszténységből eredeztetheto" szimbólumokat választottak. A kettős kereszt ősi keresztény jelkép, mely a 13. századtól állandósult a magyar nemzeti szimbólumok között (Bertényi 1996, 188.). A modern korban azonban hagyományosan a keresztény-konzervatív, illetve szélsőjobboldali mozgalmak, pártok által használt jelképpé is vált. A szerb 
ortodox kereszt ugyancsak keresztény szimbólum, és a kettős kereszthez hasonlóan szerepel ugyan Szerbia hivatalos címerében, de egyértelműen köthető a szélsőjobboldali mozgalmakhoz is. E szimbólumok használata tehát értelmezhető olyan módon, hogy a két nemzet szembenállása vallási-kulturális gyökerü is, illetve hogy mindkét etnikum esetében a szélsőségesekhez köthetők az ellentétek, konfliktusok.

Egy szerb lány rajza sokkal könnyebben felfejthető szimbólumokkal festi le a temerini helyzetet (18. melléklet). A kép bal oldalát egy véres tôr uralja, amelyet nemrég mártottak valakibe, a piros vér még csöpög a pengéről. A rajz közepén egy bokszer, egy pisztoly és egy baseballütő, tehát további fegyverek szerepelnek. Az egyébként is véres rajz a jobb felső sarokban elhelyezett szöveges üzenettől kap egyértelmű etnikai tartalmat. Itt egy kopasz férfifejet látunk, amelyet sebek és vágások csúfítanak. A férfi arca mellett a szerb címer kezdetleges rajza szerepel, alatta angolul a felirat: „I'm a Serbian!!! in Temerin” (,Szerb vagyok!!! Temerinben") és egy szomorú hangulatjel. Ez az egyértelműsítő részlet ugyan a papír kis részét fedi és periferiális helyen szerepel, a korábbi két rajztól eltérően azonban egyértelműen és egyedül a szerbeket tekinti áldozatnak. A kép készítője az akkoriban zajlott, szerb fiatalokat ért támadásból meríthetett. Az ugyan nem derül ki, hogy magyarok verték volna meg a férfit, a kép azonban azt sugallja, hogy ez egy szerb sorsa Temerinben. Minden bizonnyal az sem véletlen, hogy ezen a rajzon - az összes közül egyedüliként -, angol magyarázat szerepel; joggal feltételezhetjük, hogy ez a rajz mintegy üzenetként szolgált a két Magyarországról érkezett magyarnak, akik szerbül biztosan nem tudnak, viszont a szerző mindenképp fontosnak tartotta megmagyarázni az ábrázoltakat, a helyzetet, bemutatni a saját álláspontját, úgy, hogy azt a két idegen is megértse.

Utolsónak egy magyar lány rajzát választottuk, amely talán a legkomplexebb módon festi le a temerini viszonyokat (19. melléklet). A lapot éles vonallal két részre osztotta. A felső rész címe „Verekedések”. A feketére színezett háttérben két ökölbe szorított, ütésre kész kézfejet látunk. A jobb oldalon a "Szerbek" felirat, illetve fölé rajzolva egy baseballütő látható. A bal oldali ököl a magyaroké, fölötte kés. A rajz ismét szembeállítja a magyarokat és a szerbeket, akik egymással harcban állnak, sőt a rajzoló (talán) jellemzőnek ítélt fegyvereket is ad a kezükbe. A kép alsó részének címe „Barátok”, és mosolygós, egyforma pálcikaemberkéket ábrázol, akiket szívek vesznek körül. A lap két fele közti hangulatkülönbség szembeszökő: a lenti fehér háttéren szereplő idilli képen mindenki barát, mindenki egyenlő, egyáltalán nincsenek különbségek. Mindezt azonban mintegy beárnyékolja az agresszió, amely a kép tanúsága szerint ugyanúgy része a temerini hétköznapoknak, és egyértelműen magyarok és szerbek közti erőszakos konfliktust jelent. A két térfél közti kontraszt érzékletesen utal arra, hogy barátság, jó viszony és a véres verekedések egy helyen, egy térben, egy településen zajlanak, és a gyakori etnikai incidensek beárnyékolják a harmonikus interetnikus viszonyokat, a szerbek és magyarok közt létező barátságokat is. 


\section{Összegzés}

A kilencvenes évek háborúi és azok következményei alapvetően új környezetet hoztak létre Temerinben is, amelyben a hetvenes-nyolcvanas évek vajdasági és jugoszláviai etnikus szomszédsági tapasztalatai nem tapasztalhatók, nem élhetők újra. A Temerinben letelepedő szlavóniai és boszniai szerb menekültek magyar interjúalanyaink elbeszéléseiben „balkáni”, kulturálatlan, a helyi normákhoz alkalmazkodni nem tudó/akaró csoportként jelennek meg. A beszédmód és a csoport jellemzése, az „őslakosok” és a „,betelepülők” elhatárolására használt jelzők és kifejezések, úgy véljük, megfeleltethetők egyfajta orientalista diskurzusnak, amelyben az őslakosok „,közép-európai” világához képest az újonnan érkezők a „balkáni”, fejletlen világot képviselik. Ebből a szempontból a korábbi szerb telepesek már a közép-európai, a vajdasági (magasabb) normákat átvett, „,integrálódott” csoportként jelennek meg.

A két helyi iskola magyar és szerb tanulói körében végzett mentális térképezés arra mutatott rá, hogy ezek a konfliktusok, az erőszak jelen van a leginkább érintett generáció mindennapjaiban, azonban fontos hangsúlyoznunk, hogy a diákoknak csupán töredéke utalt a konfliktus etnikai jellegére. Ezt talán értékelhetjük úgy is, hogy kétségkívül sokak fejében él Temerin mint konfliktuszóna, ahol azonban ezek az ellentétek (még) nem egyértelműen és nem kizárólag etnikai természetűek.

Az etnikai szerkezet tartományi és települési szintű változásai a helyben korábban akár többségi helyzetben lévő magyarok gazdasági, munkaerő-piaci, politikai pozícióit, mobilitási esélyeit is megváltoztatták. A temerini magyar interjúpartnereink által a szegregáció, a kölcsönös elzárkózás, gettósodás és öngettósítás kapcsán megfogalmazott kritika, önkritika azt az általánosabb dilemmát jeleníti meg, hogy vajon az új helyzetben és környezetben lehet-e s miként megmaradni kisebbségi magyarnak, egyúttal fenntartani a jó szomszédságot, megőrizni és kialakítani az együttélés régi vagy új mintázatait.

\section{Jegyzetek}

1 Tizenkét interjút készítettünk temerini magyarokkal. Nagy Imrének ezúton is köszönetet mondunk az interjúpartnerek megtalálásában nyújtott segítségéért.

2 A kognitív vagy mentális térképek tanúskodnak az egyének térhasználatáról, többek között arról, hogy adott térben (falu, város stb.) milyen útvonalakat használnak, mit tartanak központnak, milyen emblematikus motívumok mentén tájékozódnak, illetve hogy az adott lakónegyedet, utcát miként ítélik meg. A mentális térképezés módszerét több tudomány alkalmazza, de gyakorlati célokat is szolgál például a területfejlesztésben, várostervezésben (Letenyei 2006). A mentális térképek rajzoltatása során vagy azt követően készített interjúval még pontosabb képet kaphattunk volna, de szerb nyelvtudás híján le kellett mondanunk az ily módon megszerezhető többletismeretről. 
A tanulmány írásakor a Magyar Szó online 2013. március 29-i cikkében arról tudósított, hogy Temerin község képviselőtestülete heves vita után, de megszavazta újabb telkek odaítélését menekültek számára Temerinben és Bácsszőregen (Sireg). (Több rendet a plakátragasztásban. Magyar Szó online, 2013. március 29.)

További részletek itt: Temerini Újság, 2008.december 18. XIV. évfolyam, 50. szám (716. szám).

Noha a magát magyarnak valló népesség számának és arányának csökkenése a Vajdaságból külföldre irányuló migrációnak és a részint ebből fakadó elöregedésnek is köszönhető, beszélgetőpartnereink az etnikai arányok megváltozásának értelmezésekor a szerb betelepedésre helyezték a hangsúlyt.

6 Mindössze egy idősebb magyar asszonnyal beszéltünk, aki szerint a menekültek érkezése jótékony hatással volt a községre, mert felpezsdítette a helyi kereskedelmet, szolgáltatásokat, „városiasabbá” tette Temerint.

7 Egy városi politikus annak a véleményének adott hangot, hogy „szerencse a szegregált elhelyezkedés, mert az, hogy elejibe külön vannak, segíti az adaptációt". Ő mondta azt is, hogy (már) nincsenek konfliktusok, nem is igen voltak, mert a temerini magyarok apátiával fogadták a menekültek megjelenését, csak akkor hördültek fel, amikor a menekülteket a magyar iskolában akarták elszállásolni, s ezt sikerült is megakadályozniuk. Az ő szavai arra is felhívták a figyelmet, hogy a kisebbségi politizálás is bezárhatja a közösséget; véleménye szerint a kisebbségi politikusoknak nemcsak a kisebbségi érdekképviselettel kell foglalkozniuk, de a „nagypolitika” kérdéseiben is állást kell foglalniuk. (M., helyi politikus)

A verekedések szinte kivétel nélkül péntek este és hétfö reggel között történnek, rendszerint valamelyik éjjel is nyitva tartó szórakozóhely közelében. (A kilencvenes évek hordaléka. Magyar Szó online, 2013. február 16.)

9 A gyülöletkeltő falfirkák feliratai a magyarok ellen szólnak (pl.: „Smrt Mađarima”/,Halál a magyarokra"), de a homoszexuálisok elleni uszítás is előfordult már. (Nemzeti gyűlöletet keltő falfelirat Temerinben. Vajdaság Ma, 2013. január 23.)

10 A város egyik kedvelt, magyar tulajdonú pékségéről-cukrászatáról, amely Temerinben és Tiszaistvánfalván (Járek/Bački Jarak) is több boltot üzemeltet, azt híresztelték, hogy nem ad el kenyeret szerbeknek és szerb tulajdonossal rendelkező boltoknak. (Rafinált hisztériakeltés. Temerini Újság, XVII. évfolyam, 40. szám - 862. szám)

11 2004-ben öt magyar fiatal bántalmazott egy szerb férfit Temerin belvárosában, aki súlyos sérüléseket szenvedett. A bíróság gyors eljárást követően a vádlottakat tíztől tizenöt évig terjedő (összesen 61 év) szabadságvesztésre ítélte. Az eset és az azt követő rendőrségi nyomozás, illetve a bírói döntés óriási felháborodást keltett a vajdasági magyar társadalomban. Az eset kapcsán kifogásolják a nem megfelelő rendőrségi nyomozást, míg az összesen 61 év szabadságvesztésről szóló bírói ítéletet méltánytalannak és eltúlzottnak vélik, mivel Szerbiában háborús bűnök elkövetéséért szabnak ki hasonló súlyú (tíz évet meghaladó) börtönbüntetést. Az ügy a vajdasági magyarokat hátrányosan megkülönböztető „kettős mérce” iskolapéldájává, hivatkozási alappá vált. A temerini fiúk történetéből 2012-ben egy könyv is napvilágot látott a Sötétség árnyékában címmel. A temerini fiúk ügyében az egymást követő magyar kormányok (Gyurcsány, Orbán) is szót emeltek, a legmagasabb szintű miniszterelnöki és elnöki találkozók témája volt. 2012 novemberében két elítélt elnöki kegyelemben részesült és elhagyhatta a fegyházat.

12 Az Obraz (Otačastveni pokret Obraz / Obraz Hazafias Mozgalom) szerb szélsőjobboldali mozgalom, amely a szerb nemzet, a szerb ortodox vallás és egyház, általában a szerb érdekek védelmét hirdeti. A szervezet nyíltan homofób, antiszemita és kisebbségellenes nézeteket vall, eszköztárában a megfélemlítés (halálos fenyegetések) és agresszív utcai tömegakció is szerepel. Ezek közül a leghírhedtebb a 2010-es belgrádi melegfelvonulást erőszakba fojtó rendbontás, amely miatt a szervezet vezetőjét, Mladen Obradovićot jogerősen két év fegyházbüntetésre ítélték. 2013. február 1-jén az ítéletet másodfokon megsemmisítették.

13 A magyar iskola igazgatójának közlése alapján.

14 Temerini Újság, 2011. november 3. XVII. évfolyam, 4. szám (866. szám)

15 A jugoszláv időkre emlékezve is gyakran említették beszélgetőpartnereink a sport interetnikus szomszédsági kapcsolatainak jelentőségét. A sport többek között lehetőséget adott a szerb nyelv elsajátítására is. 
16 Erőss Ágnes és Tátrai Patrik.

17 Feszültségektől terhes Temerin. Vajdaság Ma, 2011.szeptember 29., Temerin: letartóztatták az Obraz nyolc tagját, Vajdaság Ma, 2011. szeptember 30.

18 Az iskoláról lásd bővebben Ristić, Nagy, Kicošev (2013b) cikkét.

19 Mindkét iskola közel fekszik a központhoz. A Lukijan Mušicki iskola a Petőfi utca végén, a korábbi Szécsen-kastély épületében, a volt kastélypark, ma a város legnagyobb parkja mellett található. A Petőfi utcában több éjszakai szórakozóhely is sorakozik.

20 Több, Magyarországra áttelepült interjúalanyunk hasonlóan beszélt vajdasági gyerekkori élményéről. Például egyik német, szerb és magyar felmenőkkel rendelkező, német és szerb anyanyelvű, de magyarul is beszélő interjúalanyunk így vall egy kis bácskai településen élő szüleiről: „(...) egy kicsit saját világban éltek. Tehát úgy gondolták, hogy, ö... és ebból a szempontból tudok is érteni, amikor bezárják a háznak a kapuját, akkor már saját világban vannak, és semmi más nem érdekes. És körülbelül így élnek most is."

21 A szerb kiscímer a szerb címerben is szerepel. A négy cirill „sz” betű a szerb nemzeti mottót jelképezi, amelynek két értelmezése ismert: Csak az egység menti meg a szerbet; vagy Szent Száva - szerb dicsőség/ünnep.

\section{Irodalom}

Bakić-Hayden, M. (1995): Nesting orientalisms: the case of former Yugoslavia. Slavic Review, 4., 917-931.

Bertényi I. (1996): A magyar szent korona. Magyarország címere és zászlaja. Kossuth Könyvkiadó, Budapest

Bodó J., Biró A. Z. (2000): Szimbolikus térfoglalási eljárások. In Bodó J. (szerk.): Miénk itt a tér? Szimbolikus térhasználat a székelyföldi régióban. KAM, Regionális és Antropológiai Kutatások Központja, Csíkszereda, 9-42.

Brubaker, R., Feischmidt M., Fox, J., Grancea, L. (2011): Nacionalista politika és hétköznapi etnicitás egy erdélyi városban. L'Harmattan, Budapest

Erőss Á., Tátrai, P. (2010): Ethnic features of symbolic appropriation of public space in changing geopolitical frames - the case of Oradea/Nagyvárad. Hungarian Geographical Bulletin 1., 51-68.

Kliot, N., Mansfield, Y. (1997): The political landscape of partition. The case of Cyprus. Political Geography, 6., 495-521.

Letenyei L. (2005): Mentális térkép szerkesztése. In: Letenyei L.: Településkutatás. L’Harmattan, Ráció Kiadó, Budapest, 147-185.

Nagy I., Tátrai P. (2013): A migráció hatása Temerin népességnövekedésére és etnikai szerkezetének átalakulására. Tér és Társadalom, 2., 134-146.

Nedeljković, S. (2011): Ethnicity in multicultural borderlands: ethnic relations between Germans and Montenegrins in Vojvodina after World War Two. International conference: (Re)integration and development issues in multicultural and border regions. Portorož, Szlovénia. 2011. szeptember 22-24. (konferencia-előadás).

Nedeljković, S. (é.n.): The culture of memory of Montenegrin immigrants in the village of Lovćenac in Vojvodina. (kézirat)

Ristić, D., Nagy I., Kicošev, S. (2013a): Szerb menekültek Temerinben: identitás és integráció. Tér és Társadalom, 2., 147-158.

Ristić, D., Nagy I., Kicošev, S. (2013b): „Hely” és identitás. Egy temerini középiskolások körében végzett vizsgálat tanulságai. Tér és Társadalom, 2., 159-170.

Váradi M. M. (2013): Migrációs történetek, döntések és narratív identitás. A tanulmányi célú migrációról - másként. Tér és Társadalom, 2., 96-117. 
3. melléklet

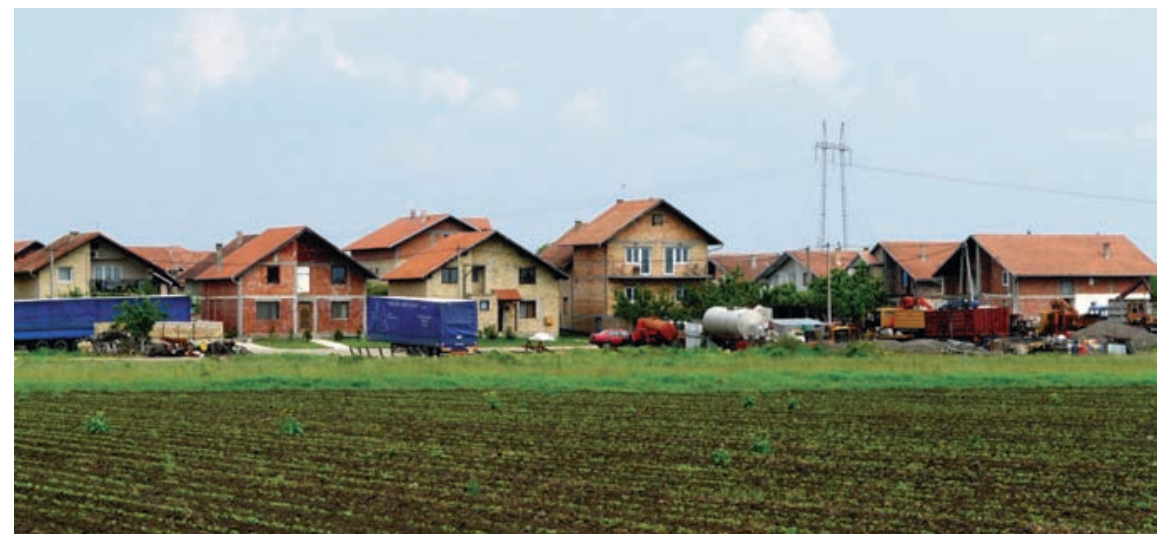

4. melléklet

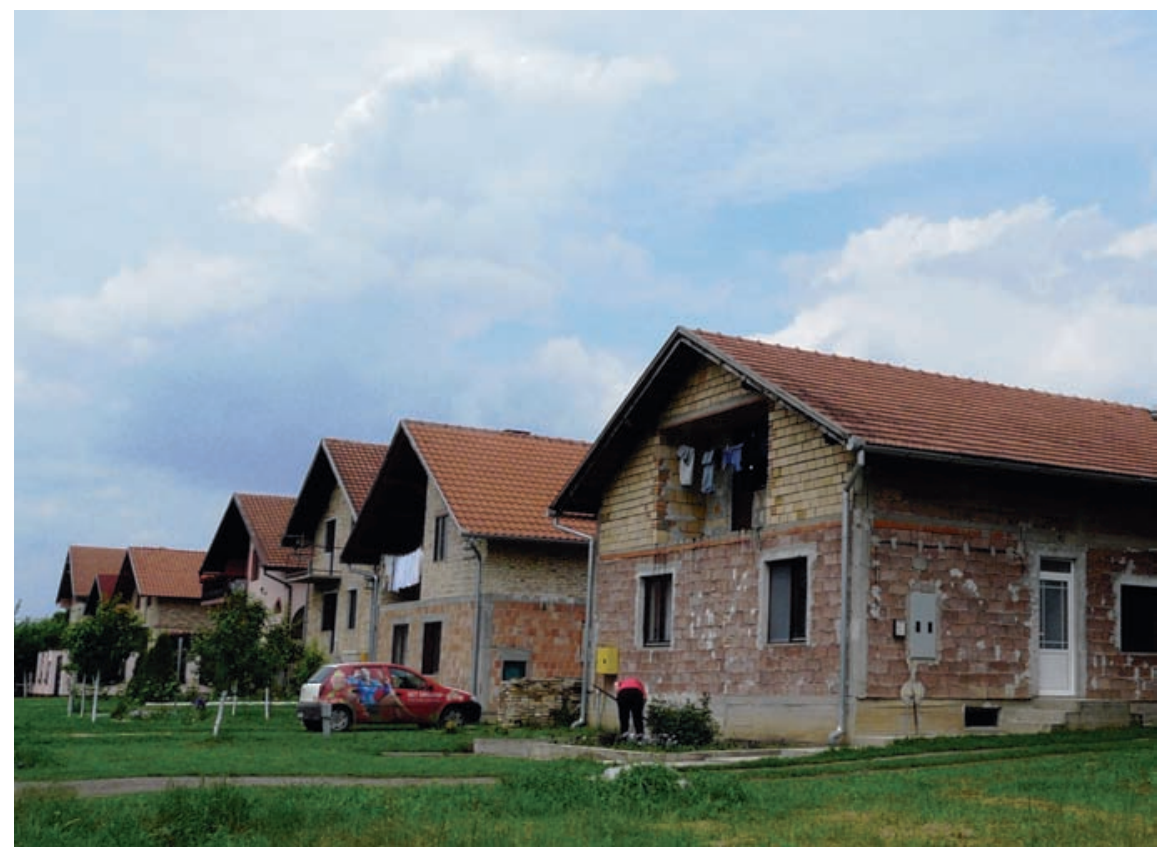


5. melléklet

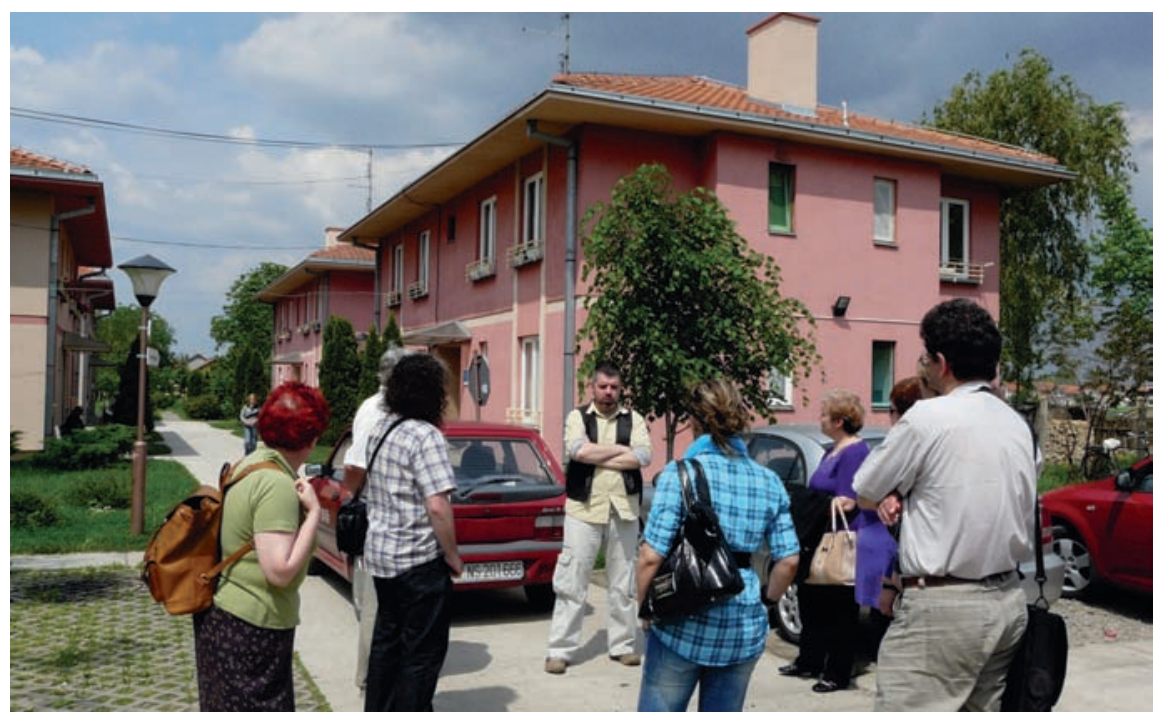

6. melléklet

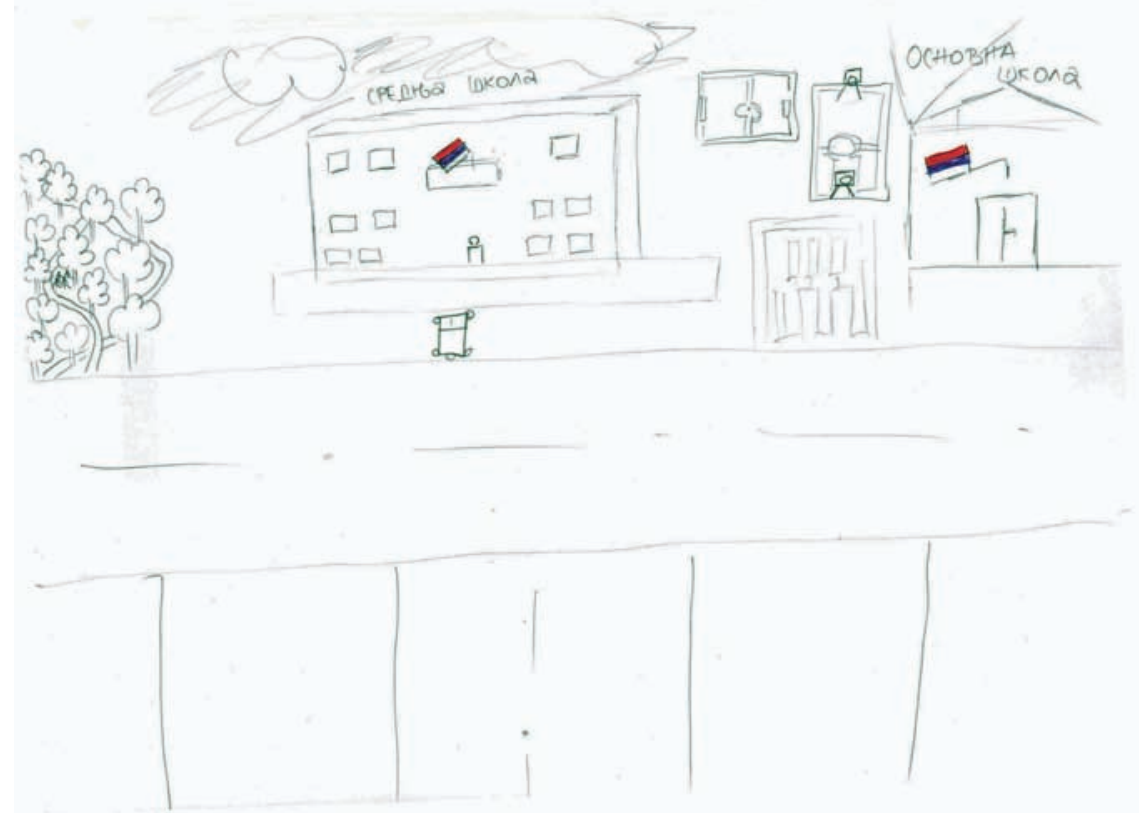


7. melléklet
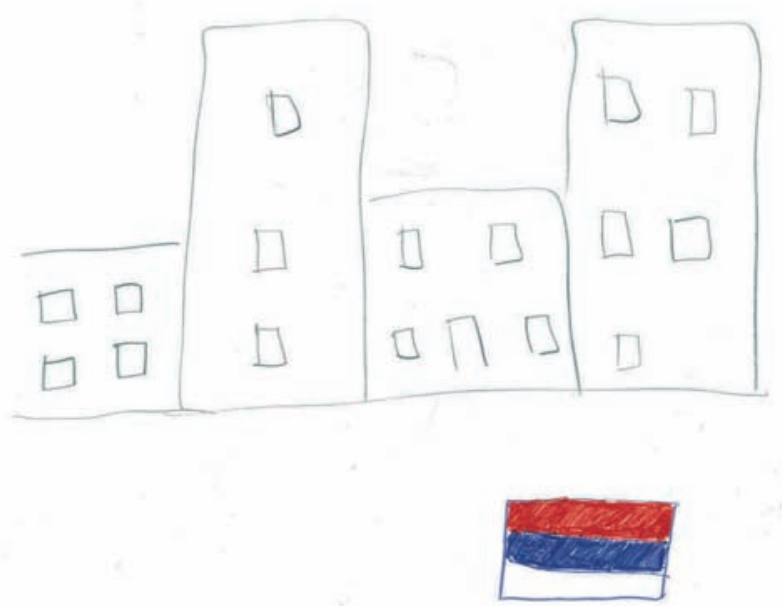

CPE UJA

8. melléklet

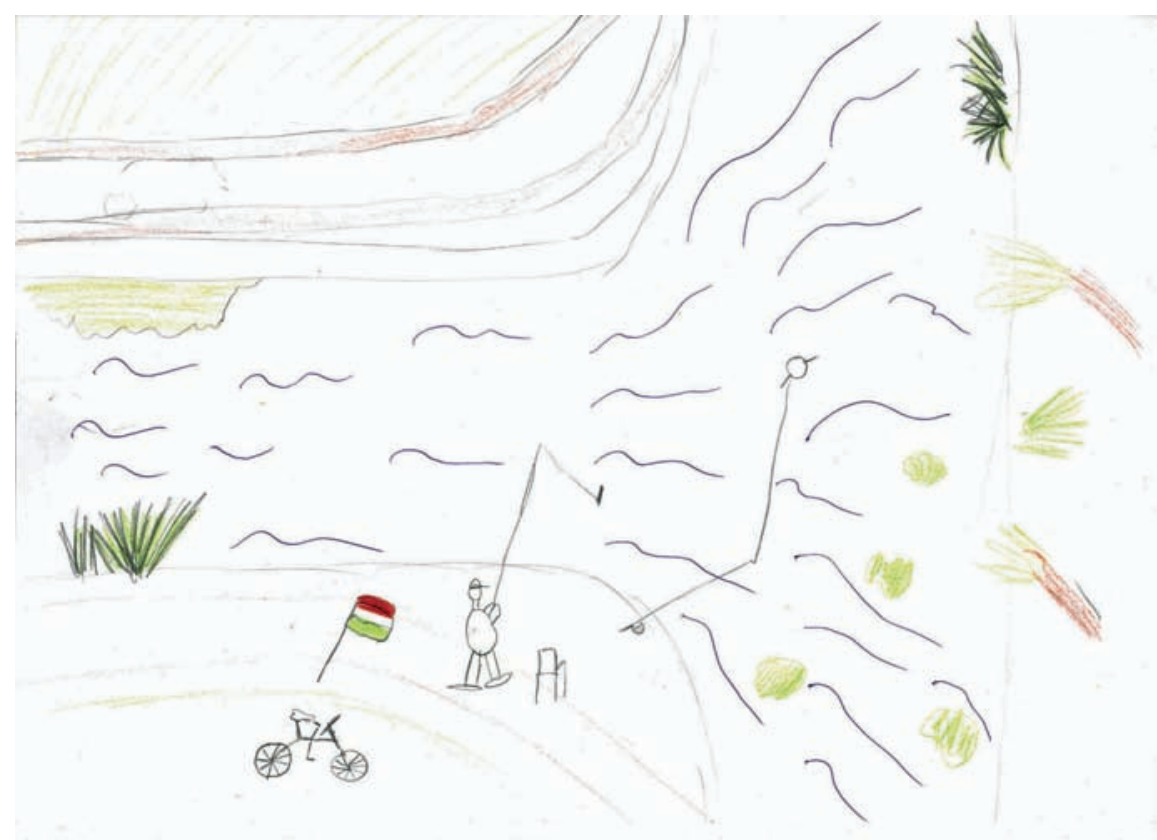


9. melléklet
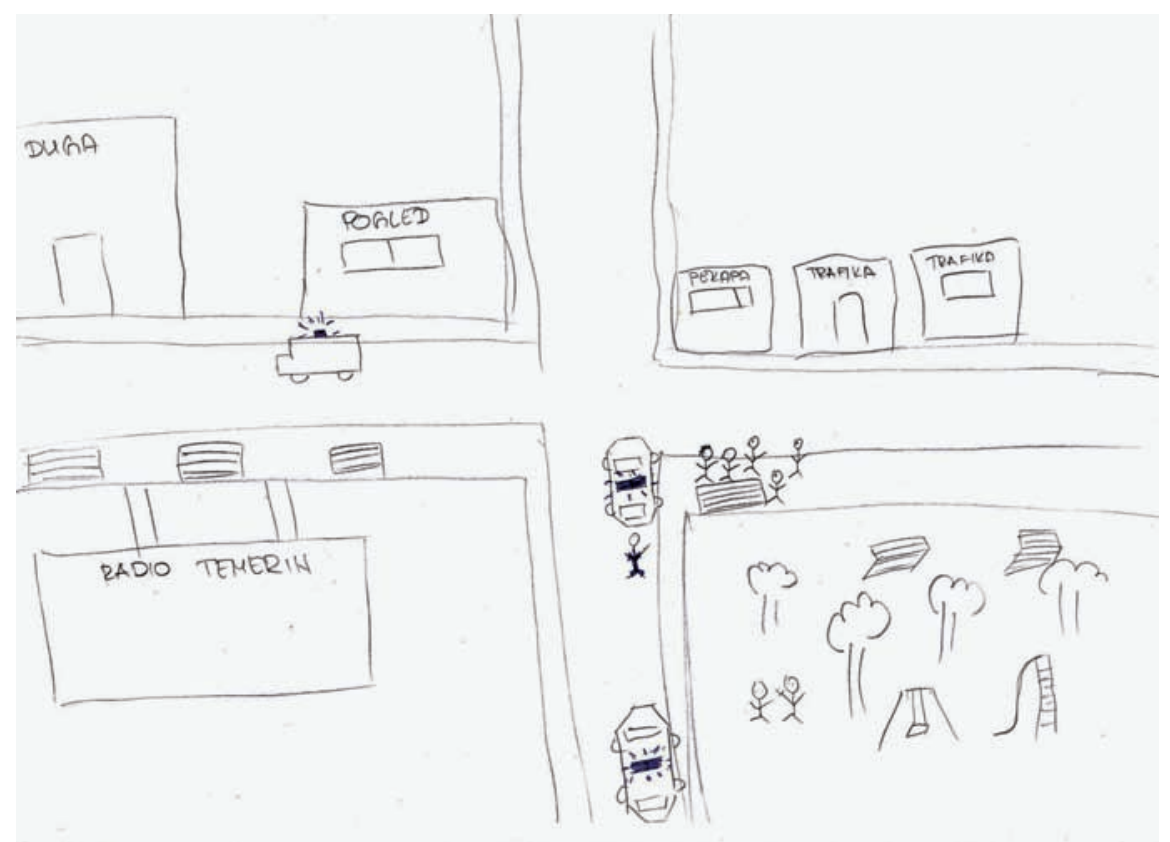

10. melléklet

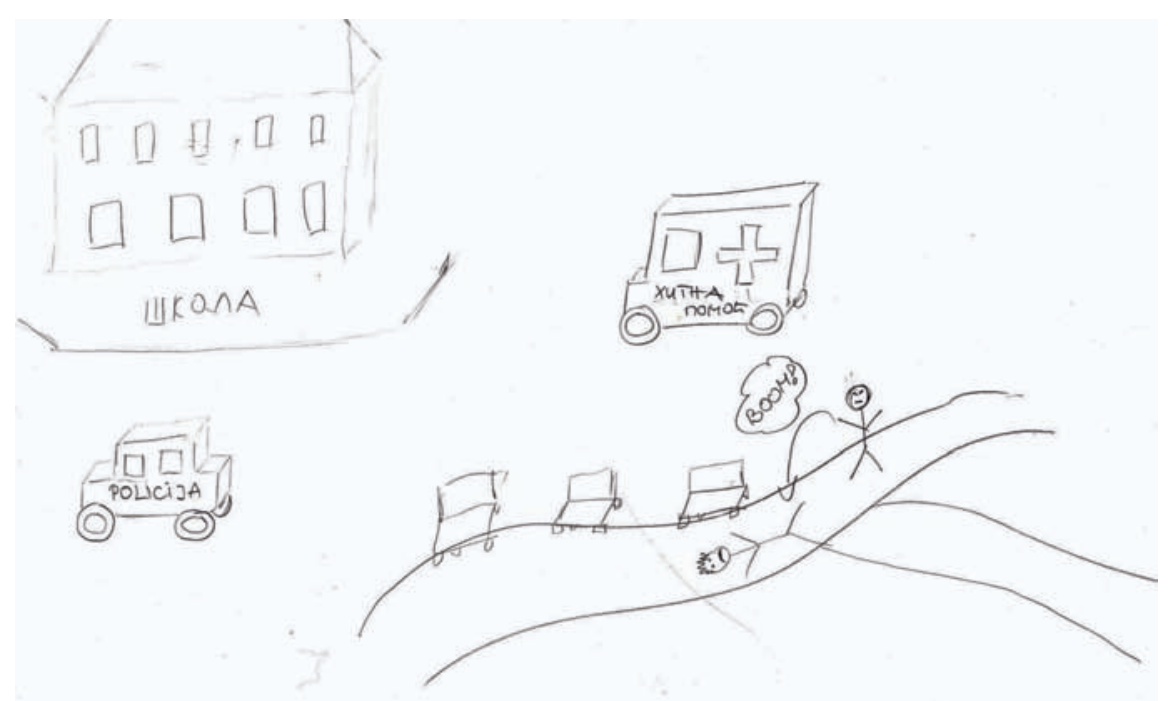


11. melléklet
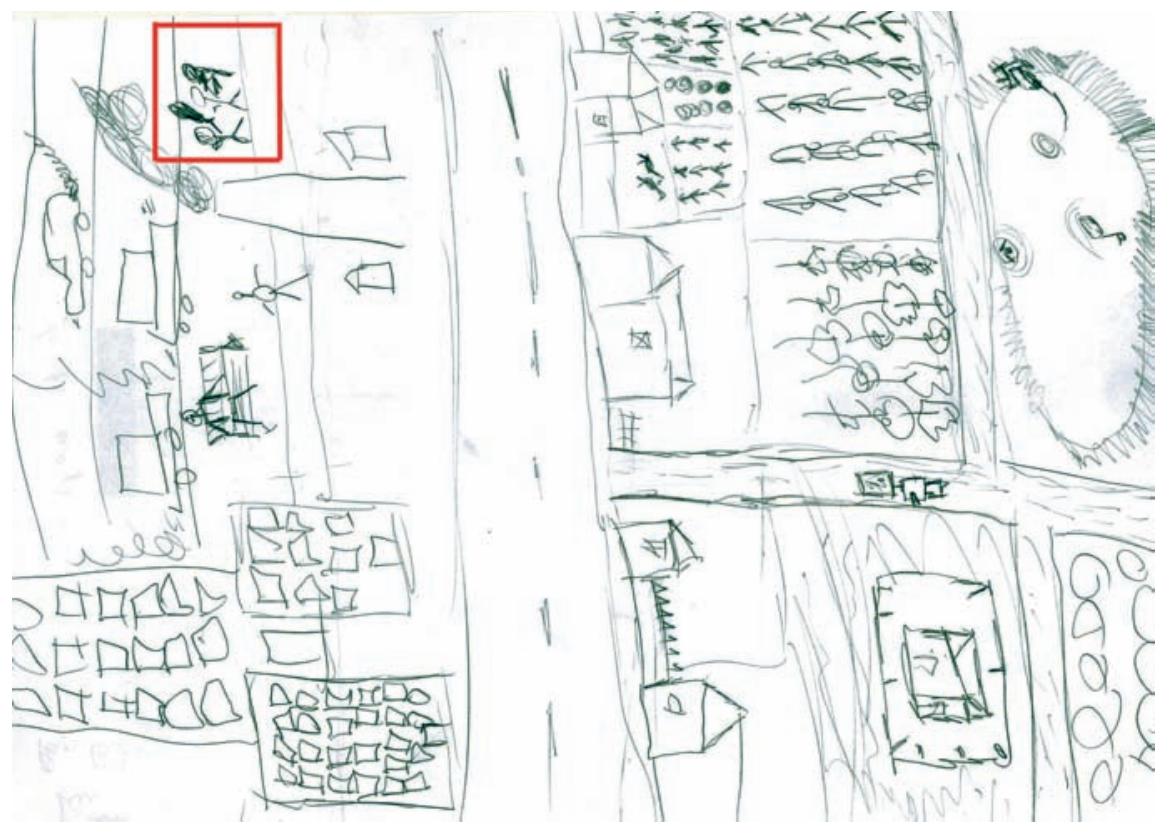

12. melléklet

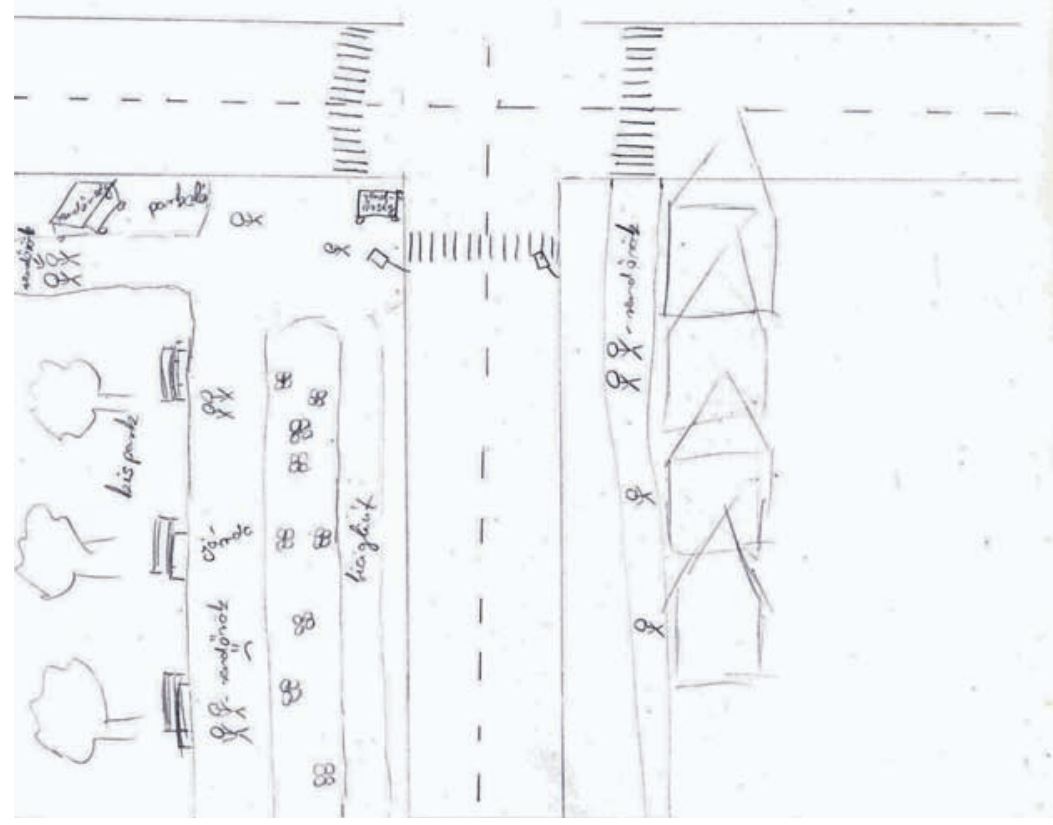


13. melléklet

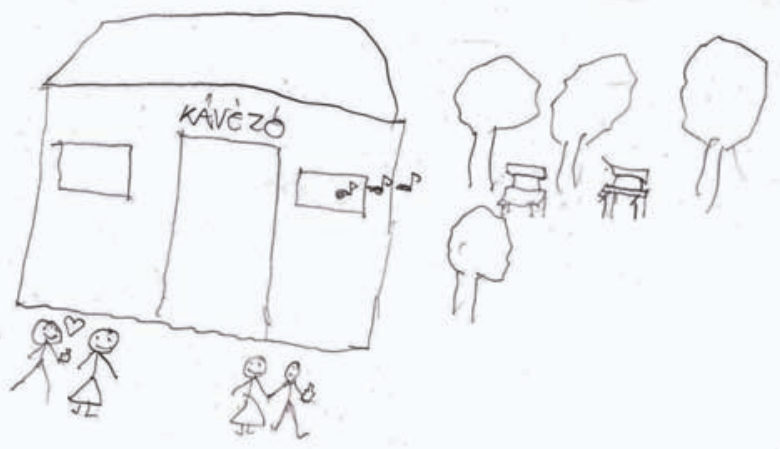

Rinc?

14. melléklet

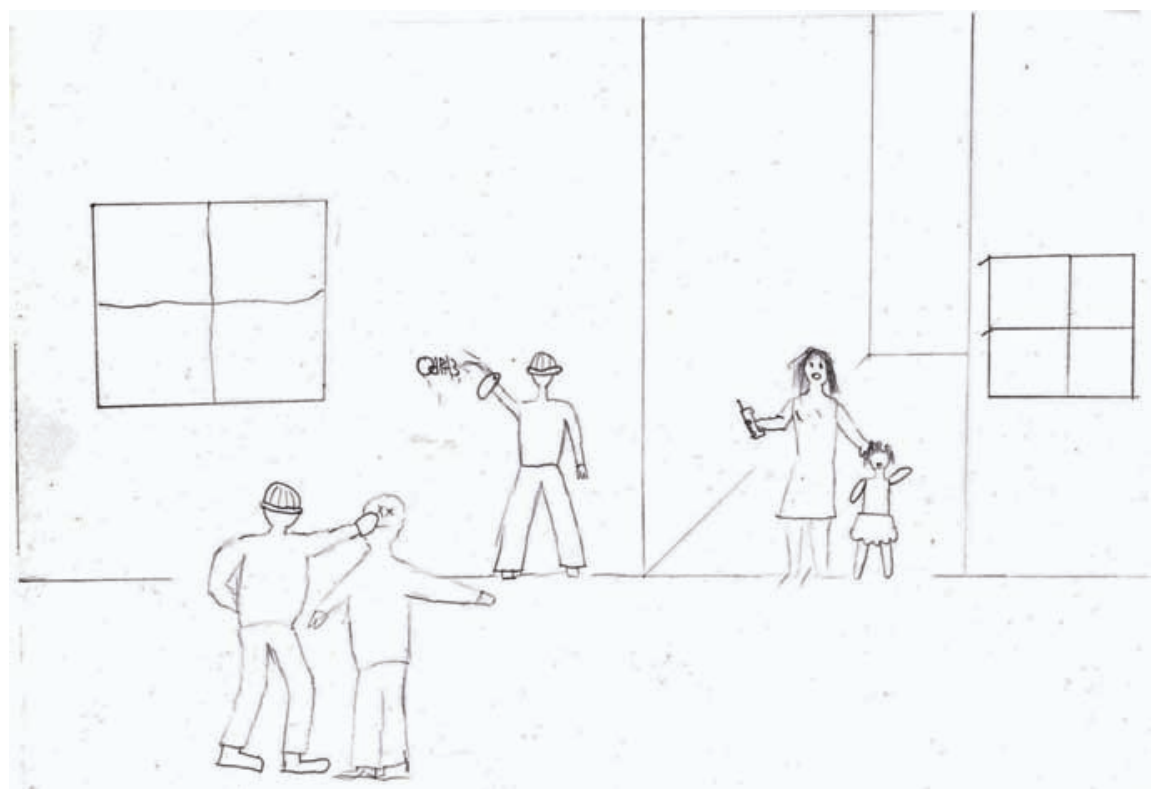


15. melléklet

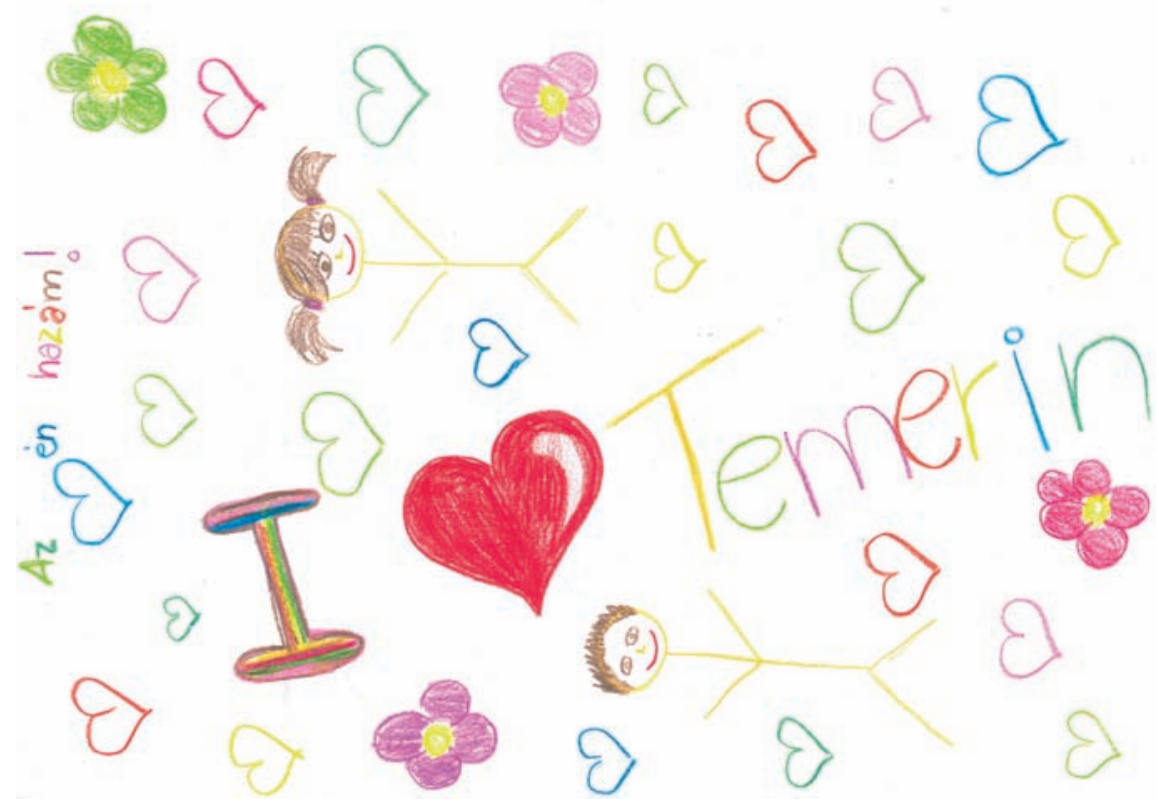

16. melléklet

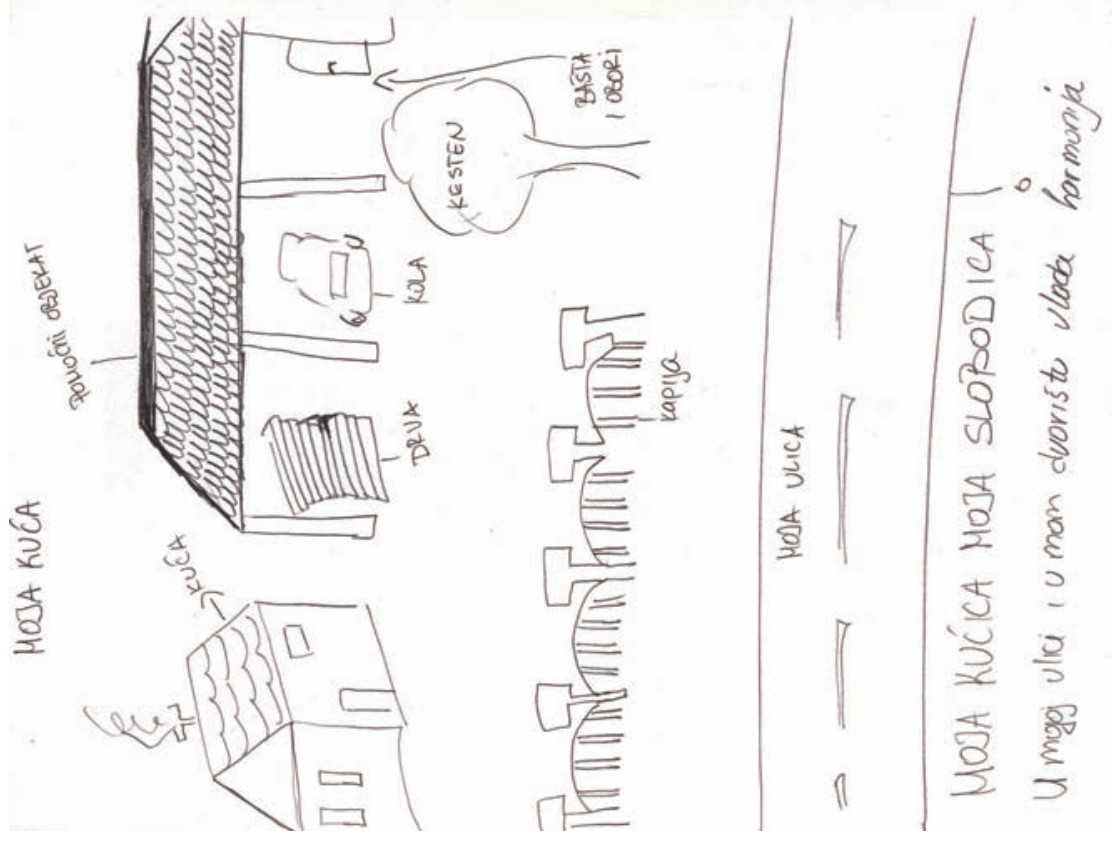


17. melléklet
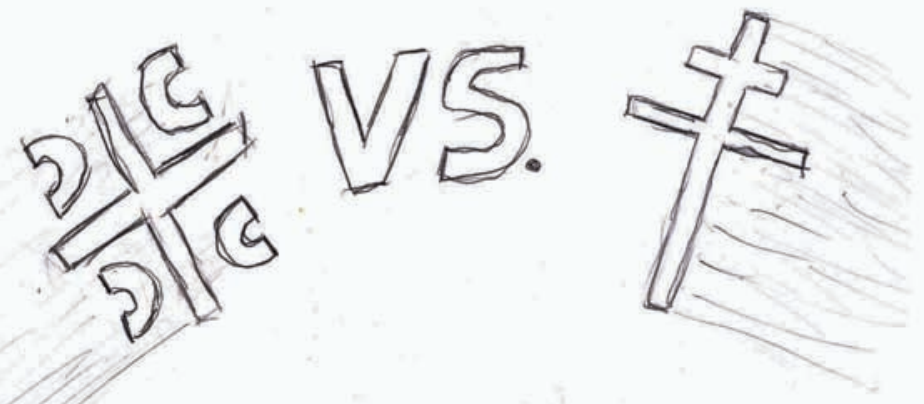

18. melléklet
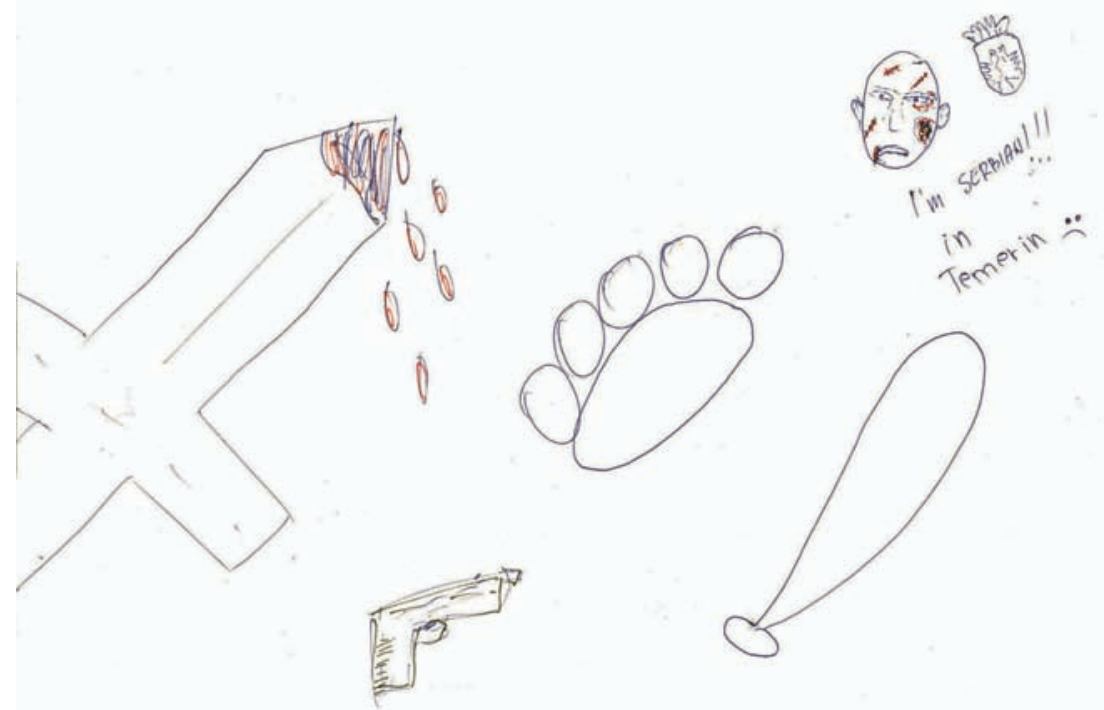
19. melléklet

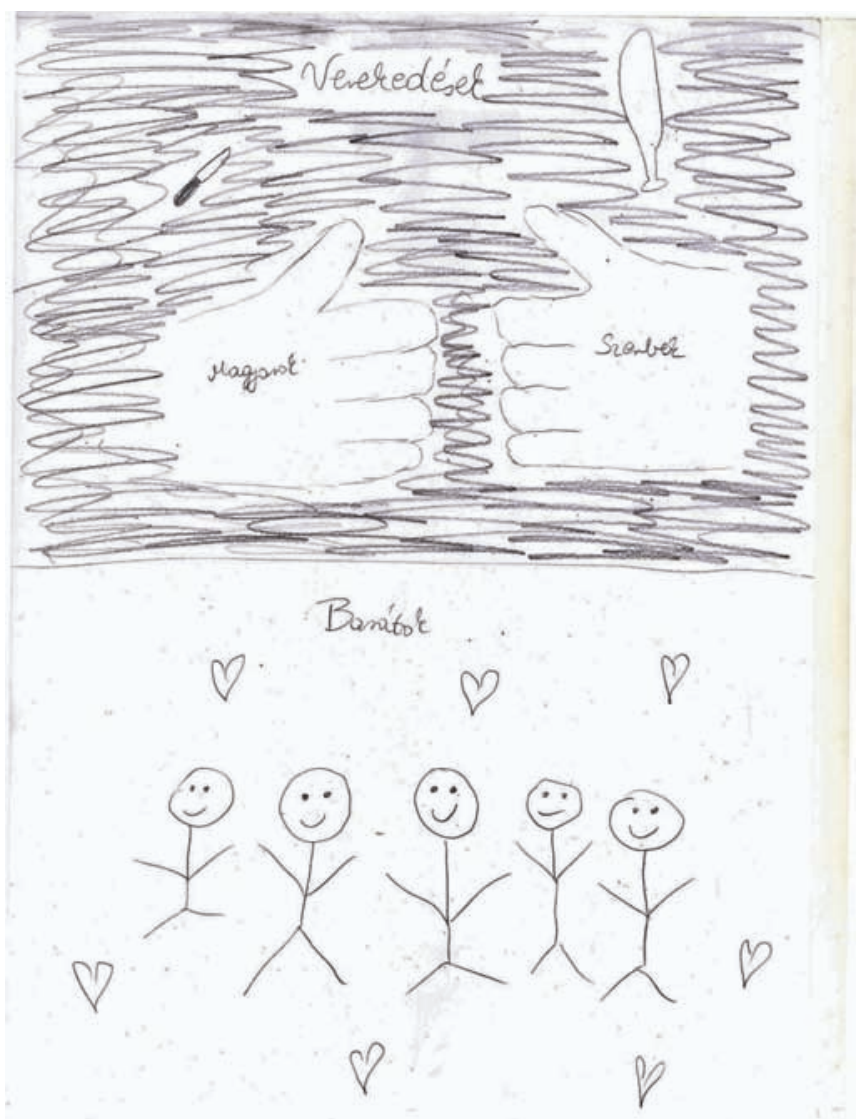

